Biogeosciences, 10, 6357-6373, 2013

www.biogeosciences.net/10/6357/2013/

doi:10.5194/bg-10-6357-2013

(c) Author(s) 2013. CC Attribution 3.0 License.

\title{
Riverine influence on the tropical Atlantic Ocean biogeochemistry
}

\author{
L. C. da Cunha ${ }^{1,2,{ }^{*}}$ and E. T. Buitenhuis ${ }^{1, *, * *}$ \\ ${ }^{1}$ Max-Planck-Institut für Biogeochemie, Postfach 100164, 07701, Jena, Germany \\ ${ }^{2}$ GLOMAR-MARUM, Universität Bremen, Leobener Strasse, 28359, Bremen, Germany \\ *now at: Faculty of Oceanography, Rio de Janeiro State University - UERJ, Rua S. F. Xavier, 524, 20550-103, Rio de Janeiro, \\ RJ, Brazil \\ ** now at: LGMAC, School of Environmental Sciences, University of East Anglia, NR4 7TJ Norwich, UK \\ Correspondence to: L. C. da Cunha (lcotrim@uerj.br)
}

Received: 9 January 2012 - Published in Biogeosciences Discuss.: 17 February 2012

Revised: 2 August 2013 - Accepted: 19 August 2013 - Published: 9 October 2013

\begin{abstract}
We assess the role of riverine inputs of $\mathrm{N}, \mathrm{Si}, \mathrm{Fe}$, organic and inorganic $\mathrm{C}$ in the tropical Atlantic Ocean using a global ocean biogeochemistry model. We use a standard model scenario and three sensitivity tests to investigate the role of total river nutrient and carbon inputs, as well as the western (South American) and eastern (African) river inputs on the tropical Atlantic Ocean biogeochemistry, between $20^{\circ} \mathrm{S}-20^{\circ} \mathrm{N}$ and $70^{\circ} \mathrm{W}-20^{\circ} \mathrm{E}$. Increased nutrient availability from river inputs in this area (compared to a sensitivity scenario without river nutrient inputs, NO_RIVER) leads to an increase in primary production (PP) and export production (EP), mainly in the coastal ocean area (modeled ocean area with bathymetry $<200 \mathrm{~m}$ ). Model results suggest an enhanced $\mathrm{N}$-fixation by diazotrophs on the tropical Atlantic mainly in open ocean areas. The increased rate of $\mathrm{N}$ fixation in the TODAY scenario is proportional to the increase in PP and EP relative to the NO_RIVER scenario, and may support up to $14 \%$ of the coastal ocean export production. Inputs from South American rivers have an impact in coastal PP and EP two times higher than those from African rivers. On the other hand, results suggest that the contribution of African and South American rivers to the total increase in open ocean PP and EP is similar. Considering the amount of delivered nutrients (2-3 times less nutrients and carbon inputs by African rivers) one concludes that African riverine inputs may have a larger impact on the whole tropical Atlantic Ocean biogeochemistry. This is probably due to a combination of nutrient trapping in upwelling areas off the large rivers' outflows and shallow mixed layers in the eastern tropical Atlantic, concomitantly to the differences in delivered nutrient ratios leading to alleviation in limitation
\end{abstract}

conditions, mainly for diatoms. When river inputs are added to the model, we estimate a modest decrease in open ocean sea-air $\mathrm{CO}_{2}$ fluxes $\left(-5.2 \mathrm{Tg} \mathrm{Ca}^{-1}\right)$ and an increase in coastal ocean $\mathrm{CO}_{2}$ fluxes, mainly provoked by the remineralization of riverine organic matter delivered by the South American rivers.

\section{Introduction}

The tropical Atlantic Ocean directly receives (i.e. not filtered by regional seas or enclosed coastal areas) the discharge of the three largest rivers in the world: the Amazon River $\left(0^{\circ}\right.$, $\left.50^{\circ} \mathrm{W}\right)$, the Congo River $\left(6^{\circ} \mathrm{S}, 12^{\circ} \mathrm{E}\right)$, and the Orinoco River $\left(10^{\circ} \mathrm{N}, 63^{\circ} \mathrm{W}\right)$ (Fig. 1). In this region, a weak Coriolis forcing leads to extended river plumes off the coast, creating nutrient-rich areas of optimal production in sites far removed from the coast (Corredor et al., 2003). The freshwater inputs of the three rivers represent $\sim 25 \%$ of the global river freshwater discharge to the oceans (Dai and Trenberth, 2002), and together they represent $15-18 \%$ of the total river input of organic carbon to the ocean.

The western tropical Atlantic receives massive freshwater and nutrient inputs from the Amazon and Orinoco rivers. The discharge of these rivers alone represents $20 \%$ of the total annual riverine freshwater discharge to the oceans. A persistent front of high surface chlorophyll, visible in ocean satellite color imagery, is associated with riverine inputs (Corredor et al., 2003; Hu et al., 2004; Molleri et al., 2010). The Amazon River discharge generates a plume that covers up to $2 \times 10^{6} \mathrm{~km}^{2}$ and is characterized by low salinity and low 


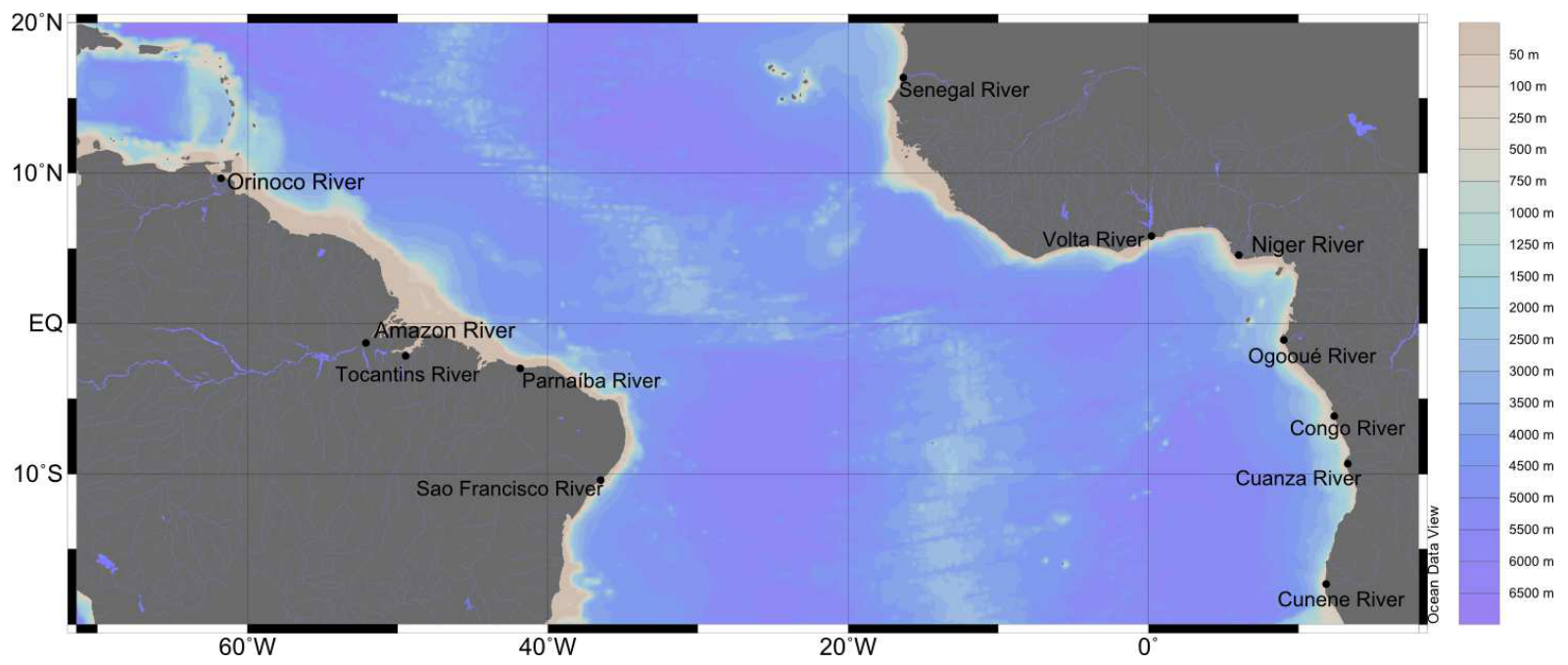

Fig. 1. Map of the tropical Atlantic Ocean showing the location of the main rivers outflow $(\bullet)$. The colored side bar represents the bottom topography (Schlitzer, R., http://odv.awi.de).

inorganic carbon concentration. The plume may reach from $50^{\circ} \mathrm{W}$ to $25^{\circ} \mathrm{W}$ during the peak flow of the North Equatorial Countercurrent (NECC) (Cooley et al., 2007; Subramaniam et al., 2008).

The Congo River delivers to the Eastern tropical Atlantic the largest freshwater input to an eastern ocean boundary. The Eastern tropical Atlantic is characterized by oligotrophic oceanic waters, but a large river plume (Congo) with elevated nutrient concentration and the Benguela Current system with strong wind-driven coastal upwelling (Cadée, 1978; Dale et al., 2002; Schneider et al., 1997) impact the local productivity (Binet, 1983; Hardman-Mountford et al., 2003). Further north, the Gulf of Guinea receives freshwater input from a dense river network leading to the coastal ocean (e.g. rivers Niger and Volta). The Gulf of Guinea is also subject to coastal upwelling, mainly between July and September (Lefèvre, 2009; Lefèvre et al., 2008).

In this study, we assess the impact of riverine input of carbon and nutrients on the western and eastern tropical Atlantic biogeochemistry. We employ recent methods to estimate river nutrient $(\mathrm{N}, \mathrm{Si}$ and $\mathrm{Fe}$ ) and carbon (DIC/dissolved inorganic carbon, DOM/dissolved organic matter, POM/particulate organic matter) inputs, and use a global ocean biogeochemistry model based on plankton functional types. We focus our results and discussion on the tropical Atlantic Ocean $\left(70^{\circ} \mathrm{W}-20^{\circ} \mathrm{E}, 20^{\circ} \mathrm{S}-20^{\circ} \mathrm{N}\right)$.

\section{Methods}

\subsection{PlankTOM10 Ocean biogeochemistry model}

We use the PlankTOM10 ocean biogeochemistry model (Buitenhuis et al., 2013b; Enright et al., 2012), which is based on plankton functional types (PFTs) as de- scribed in Le Quéré et al. (2005). PlankTOM10 was developed from the model PlankTOM5.2 (Suntharalingam et al., 2012; Vogt et al., 2010), and represents ten plankton functional groups: silicifiers (diatoms), calcifiers, picoautotrophs, DMS-producers, nitrogen fixers ( $\mathrm{N}$-fixers) and mixed phytoplankton, pico-heterotrophs, proto-zooplankton, mesozooplankton and macro-zooplankton (Enright et al., 2012). For the phytoplankton types, the model estimates total biomass in carbon units, and iron, chlorophyll, and silicon content for the silicifiers as prognostic variables. For the pico-heterotrophs and the three zooplankton size classes, only biomass is modeled. The model assumes that all PFTs have a constant $C: N: P$ ratio of $122: 16: 1$, and that their $\mathrm{Fe}: \mathrm{C}, \mathrm{Chl}: \mathrm{C}$, and $\mathrm{Si}: \mathrm{C}$ (only for silicifiers) are variable and determined by the model. The model includes phytoplankton growth co-limitation by phosphate, nitrate, silicate and iron. The nitrate pool undergoes denitrification and nitrogenlimited growth by $\mathrm{N}$-fixers that can add to the ocean nitrogen inventory. PlankTOM10 also describes dissolved inorganic carbon (DIC), dissolved oxygen, and total alkalinity. The model was forced with annual riverine nutrient (nitrate, phosphate, silicate, and iron) and carbon (DIC, alkalinity, DOM, POM) inputs as described in da Cunha et al. (2007) following a global river drainage direction map (DDM30) at $0.5^{\circ}$ increments of latitude and longitude (Döll and Lehner, 2002). In this map, the drainage directions and discharge of surface water on all continents, except Antarctica are represented. Within the map, cells connect by their drainage direction and are thus organized into drainage basins. In this study, only cells corresponding to basin outlets to the ocean are used as input points for our PlankTOM10 simulations (Fig. 2). 


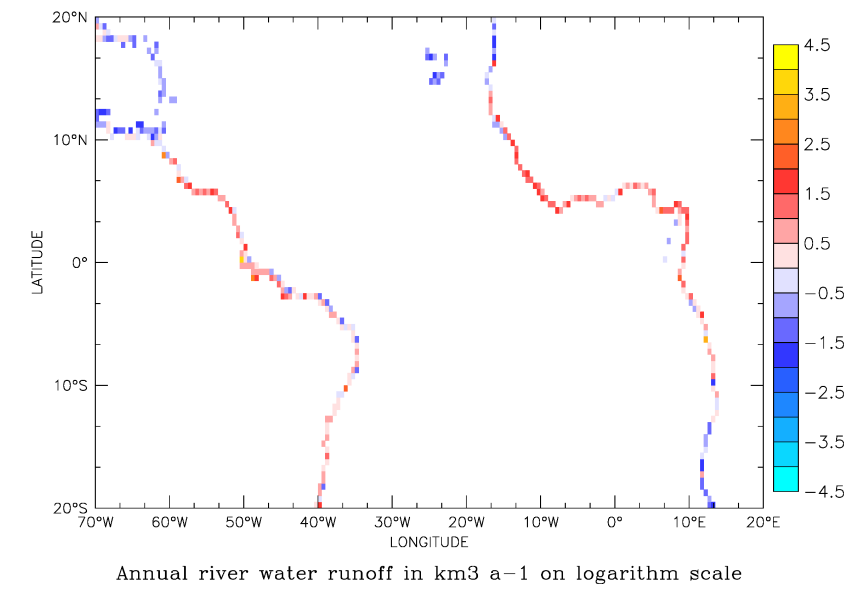

Fig. 2. Annual river freshwater input in $\mathrm{km}^{3} \mathrm{a}^{-1}$ (logarithm scale) to the Tropical Atlantic Ocean (Döll and Lehner, 2002; Korzoun et al., 1977).

\subsection{NEMO global ocean general circulation model}

PlankTOM10 is embedded in the NEMOv2.3 global ocean general circulation model (Madec and NEMO-Team, 2008). It has the longitudinal resolution of $2^{\circ}$ and latitudinal resolution of $1.5^{\circ}$ enhanced to $0.5^{\circ}$ at the equator and at the poles. The vertical resolution is $10 \mathrm{~m}$ in the upper $100 \mathrm{~m}$ and comprises 31 depth levels down to the ocean floor. The model time step in our version is $1 \mathrm{~h} 36 \mathrm{~min}$.

The model was forced by the daily wind and water fluxes from NCEP/NCAR reanalysis (Kalnay et al., 1996) from 1948 to 2005 as in Buitenhuis et al. (2006) and Jones (2003). The solar radiation penetrates the top meters of the ocean. The addition of heat is formulated with two extinction coefficients (Paulson and Simpson, 1977) whose values correspond to average open ocean conditions. The computation of photosynthetically active radiation (PAR) is also formulated with two extinction coefficients, but in this case the light absorption by the model's chlorophyll concentration is taken into account. These two separate formulations ensure that, on the one hand, the physical heating is always the same, so that interpretation of our model scenarios are not complicated by changing circulation, while, on the other hand, the shading effect of phytoplankton on primary production in subsurface layer is taken into account (Manizza et al., 2005). The effect of freshwater addition on water column stability and hence heat exchange and the distribution of phytoplankton is thus taken into account, but the effect of chlorophyll heat absorption on the physics is not. River freshwater input is computed monthly in NEMO as described by Madec and the NEMO Team (2008).

\subsection{Model scenarios}

We did four simulations with the PlankTOM10 model considering different riverine nutrient load estimates (Table 1).
We ran the simulations from 1990 to 2005 . This is long enough for the surface ocean to approximate steady state, as shown by the stability of the results after 3-4 yr of simulations. We present average output for years 1998-2005.

\section{TODAY}

This scenario considers riverine inputs of DIC, DOM, and POM estimated according to the models by Ludwig and Probst (1998), Korzoun et al. (1977) and Ludwig et al. (1996a, b). River carbon fluxes are mainly controlled by drainage intensity and lithology (DIC), basin slope, drainage intensity and soil organic matter (OM) content (DOM), and sediment flux (POM). We used a $\mathrm{C}: \mathrm{N}: \mathrm{Fe}$ ratio of $122: 16$ : $6.110^{-4}$; thus, riverine DOM and POM, when they are remineralized, also become C, N, P and Fe sources to the ocean. Dissolved inorganic nitrogen (DIN) and dissolved inorganic phosphorus (DIP) inputs were estimated based on a regression model by Smith et al. (2003). Dissolved Si inputs were calculated using the runoff data from the DDM30 map, and applying an average concentration of dissolved $\mathrm{Si}$ in river waters of $4.2 \mathrm{mg} \mathrm{Si} \mathrm{L}^{-1}$ (Tréguer et al., 1995). Additionally, the scenario has riverine $\mathrm{Fe}$ input, estimating $95 \%$ loss of dissolved $\mathrm{Fe}$ in the estuaries at low salinity, and an average concentration of dissolved iron in river waters of $40 \mu \mathrm{g} \mathrm{L}^{-1}$ (Martin and Whitfield, 1983). The literature suggests that approximately $80 \%$ to more than $95 \%$ of the riverine dissolved iron loads inside the estuary are removed from the dissolved phase at low salinities (Boyle et al., 1977; Chester and Jickells, 2012; Lohan and Bruland, 2006; Sholkovitz, 1978).

\section{NO_RIVER}

This sensitivity scenario represents an extreme situation where riverine nutrient fluxes would stop completely. We do not consider a reduction in freshwater input to the ocean.

\section{AFRICA}

This scenario is identical to TODAY but considers only African river nutrient and carbon inputs to the tropical Atlantic Ocean. The South American river nutrient and carbon inputs were stopped in this sensitivity scenario. We do not consider a reduction in freshwater input to the ocean.

\section{S_AMERICA}

This scenario is identical to TODAY but considers only South American river nutrient and carbon inputs to the tropical Atlantic Ocean. The African river nutrient and carbon inputs were stopped in this sensitivity scenario. We do not consider a reduction in freshwater input to the ocean.

We used the average of the absolute difference between modeled parameter $\left(a_{n}\right)$ and available data $\left(c_{n}\right)$ values to estimate how the model simulates chlorophyll $a(\mathrm{Chl} a)$, 
Table 1. River nutrient scenarios.

\begin{tabular}{|c|c|c|c|c|c|c|c|}
\hline \multirow[t]{2}{*}{ Scenario name } & \multicolumn{6}{|c|}{ River nutrient inputs to the tropical Atlantic Ocean $\left(20^{\circ} \mathrm{S}-20^{\circ} \mathrm{N}, 70^{\circ} \mathrm{W}-20^{\circ} \mathrm{E}\right)$} & \multirow[b]{2}{*}{$\begin{array}{l}\text { Details on riverine } \\
\text { nutrient inputs }\end{array}$} \\
\hline & $\begin{array}{l}\mathrm{OM} \\
\left(\mathrm{Tmol} \mathrm{C} \mathrm{a}^{-1}\right)\end{array}$ & $\begin{array}{l}\text { DIC } \\
\left(\mathrm{Tmol} \mathrm{C} \mathrm{a}^{-1}\right)\end{array}$ & $\begin{array}{l}\mathrm{N} \\
(\mathrm{Tmol} \mathrm{N} \mathrm{a} \\
\end{array}$ & $\begin{array}{l}\mathrm{Si} \\
\left(\mathrm{Tmol} \mathrm{Si} \mathrm{a}{ }^{-1}\right)\end{array}$ & $\begin{array}{l}\mathrm{P} \\
(\mathrm{Gmol} \mathrm{P} \mathrm{a}\end{array}$ & $\begin{array}{l}\mathrm{Fe} \\
\left(\mathrm{Gmol} \mathrm{Fe} \mathrm{a}^{-1}\right)\end{array}$ & \\
\hline NO_RIVER & 0 & 0 & 0 & 0 & 0 & 0 & No riverine inputs \\
\hline TODAY & 6.75 & 4.83 & 1.09 & 1.89 & 10.97 & 0.45 & $\begin{array}{l}\mathrm{DIN}^{\mathrm{a}}, \mathrm{DIP}^{\mathrm{a}}, \mathrm{Si}^{\mathrm{b}}, \mathrm{Fe}(95 \% \text { loss })^{\mathrm{c}}, \\
\text { DIC }^{\mathrm{d}}, \mathrm{DOM}^{\mathrm{d}}, \mathrm{POM}^{\mathrm{d}}\end{array}$ \\
\hline S_AMERICA & 5.09 & 3.91 & 0.77 & 1.37 & 5.44 & 0.33 & $\begin{array}{l}\mathrm{DIN}^{\mathrm{a}}, \mathrm{DIP}^{\mathrm{a}}, \mathrm{Si}^{\mathrm{b}}, \mathrm{Fe}(95 \% \text { loss })^{\mathrm{c}} \text {, } \\
\mathrm{DIC}^{\mathrm{d}}, \mathrm{DOM}^{\mathrm{d}}, \mathrm{POM}^{\mathrm{d}}, \\
\text { only South American rivers }\end{array}$ \\
\hline AFRICA & 1.66 & 0.92 & 0.32 & 0.52 & 5.54 & 0.12 & $\begin{array}{l}\mathrm{DIN}^{\mathrm{a}}, \mathrm{DIP}^{\mathrm{a}}, \mathrm{Si}^{\mathrm{b}}, \mathrm{Fe}(95 \% \text { loss })^{\mathrm{c}} \text {, } \\
\mathrm{DIC}^{\mathrm{d}}, \mathrm{DOM}^{\mathrm{d}}, \mathrm{POM}^{\mathrm{d}}, \\
\text { only African rivers }\end{array}$ \\
\hline
\end{tabular}

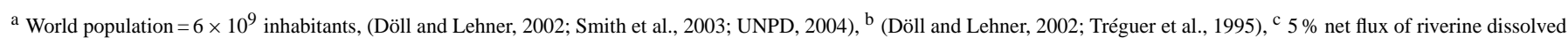
Fe to the ocean (Chester and Jickells, 2012; Döll and Lehner, 2002; Martin and Meybeck, 1979), ${ }^{\mathrm{d}}$ (Döll and Lehner, 2002; Ludwig et al., 1996a, b).

Table 2. Mean absolute error (MAE) between PISCES-T simulations NO_RIVER and TODAY (average 1998-2005) and available data for the tropical Atlantic Ocean $\left(20^{\circ} \mathrm{S}-20^{\circ} \mathrm{N}, 70^{\circ} \mathrm{W}-20^{\circ} \mathrm{E}\right)$.

\begin{tabular}{|c|c|c|c|c|c|c|c|c|}
\hline \multirow[t]{2}{*}{ Scenario name } & \multicolumn{8}{|c|}{ Mean absolute error } \\
\hline & $\begin{array}{l}\mathrm{Chl} a^{\mathrm{a}} \\
\mathrm{mg} \operatorname{Chl} a \mathrm{~L}^{-1}\end{array}$ & $\begin{array}{l}\mathrm{NO}_{3}{ }^{b} \\
\mu \mathrm{M}\end{array}$ & $\begin{array}{l}\mathrm{Si}^{\mathrm{b}} \\
\mu \mathrm{M}\end{array}$ & $\begin{array}{l}\mathrm{PO}_{4}{ }^{\mathrm{b}} \\
\mu \mathrm{M}\end{array}$ & $\begin{array}{l}\text { Diss. Fe } \mathrm{Fe}^{\mathrm{c}} \\
\mathrm{nM}\end{array}$ & $\begin{array}{l}\mathrm{PP}^{\mathrm{d}} \\
\mathrm{gC}^{-2} \mathrm{a}^{-1}\end{array}$ & $\begin{array}{l}\mathrm{EP}^{\mathrm{e}} \\
\mathrm{gC} \mathrm{m}^{-2} \mathrm{a}^{-1}\end{array}$ & $\begin{array}{l}\text { Diss. } \mathrm{O}_{2}{ }^{\mathrm{f}} \\
(\mu \mathrm{M})\end{array}$ \\
\hline NO_RIVER & 0.18 & 0.79 & 1.85 & 0.10 & 0.44 & 59.58 & 6.39 & 5.83 \\
\hline TODAY & 0.13 & 0.79 & 1.90 & 0.10 & 0.77 & 32.90 & 3.29 & 5.85 \\
\hline
\end{tabular}

Available data reference: ${ }^{\text {a }}$ surface $\mathrm{Chl} a$ estimated from SeaWiFS satellite, average 1998-2005, ${ }^{\mathrm{b}}$ surface $\mathrm{NO}_{3}, \mathrm{Si}$, and $\mathrm{PO}_{4}$ from World Ocean Atlas 2005 (Garcia et al., 2006b), ${ }^{\mathrm{c}}$ dissolved Fe data from Tagliabue et al. (2012); ${ }^{\mathrm{d}}$ primary production average 1998-2005, satellite-based estimation

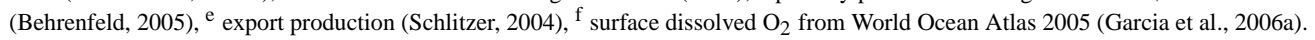

nitrate $\left(\mathrm{NO}_{3}\right)$, silicate $(\mathrm{Si})$, dissolved iron $(\mathrm{Fe})$, primary production, export production, and dissolved $\mathrm{O}_{2}$ (Eq. 1, Table 2). This also allows us to assess how riverine nutrient fluxes affect these parameters. We calculate the mean absolute error (MAE) as follows:

$\operatorname{MAE}=\frac{\left|a_{1}-a_{2}\right|+\left|a_{2}-a_{2}\right|+\ldots+\left|a_{n}-c_{n}\right|}{n}$

\section{Results and discussion}

In this section we present the model results from the TODAY scenario - which we estimate best represents the river inputs of carbon and nutrients, as well as the ocean biogeochemical features (Sect. 3.1) - and compare them with available data for the tropical Atlantic Ocean. In Sect. 3.2 we discuss the influence of river nutrients and carbon inputs on the regional tropical Atlantic biogeochemistry. Here we use the results of our NO_RIVER, S_AMERICA, and AFRICA sensitivity scenarios, and compare them to our "standard" simulation, TODAY, in order to identify the main impacts of these fluxes on this region.

\subsection{The TODAY scenario}

In our model, the Amazon, Congo and Orinoco rivers deliver $\sim 70 \%$ of the total river organic carbon to the tropical Atlantic Ocean. We generally have a good agreement between TODAY river OM inputs and data based on measurements, except in the case of the Congo River. For the Amazon, Congo and Orinoco Rivers, the TODAY scenario has $3.61 \mathrm{TmolOMa}^{-1}, 0.71 \mathrm{Tmol} \mathrm{OMa}^{-1}$, and $0.53 \mathrm{Tmol} \mathrm{OM} \mathrm{a}^{-1}$, respectively, while Coynel et al. (2005) report river inputs of $3.65 \mathrm{Tmol} \mathrm{OM} \mathrm{a}^{-1}$ for the Amazon and $1.20 \mathrm{Tmol} \mathrm{OM} \mathrm{a}^{-1}$ for the Congo, and Lewis and Saunders (1989) report $0.56 \mathrm{Tmol} \mathrm{OM} \mathrm{a}^{-1}$ for the Orinoco River. Modeled river DIC inputs to the ocean are higher for the Amazon River (3.1 Tmol DIC a ${ }^{-1}$, model, and 2.2 $\mathrm{Tmol} \mathrm{DIC} \mathrm{a}^{-1}$, (Probst et al., 1994)). For the Congo and Orinoco riverine DIC inputs, the model value is higher than the estimated flux based on measurements $\left(0.50 \mathrm{Tmol} \mathrm{DIC} \mathrm{a}^{-1}\right.$, model, against $0.29 \mathrm{Tmol} \mathrm{DIC} \mathrm{a}^{-1}$, (Congo River; Probst et al., 1994), and $0.22 \mathrm{Tmol} \mathrm{DIC} \mathrm{a}^{-1}$, model, against $0.94 \mathrm{Gmol} \mathrm{DIC} \mathrm{a}^{-1}$ (as $\mathrm{HCO}^{3-}$, Orinoco River; Lewis and Saunders, 1989). We attribute this to the difference in the methods used to estimate DIC and OM fluxes. In both cases, Congo and Orinoco rivers, the values were obtained from discharge-weighed measurements, while in this study we use river fluxes based on 
empirical models. This means that the fluxes are calculated on the basis of relationships between measured/known basin area, drainage intensity, total suspended sediments, soil, and measured concentrations of carbon and nutrients in selected (where data is available) rivers (Ludwig et al., 1996b; Smith et al., 2003; Tréguer et al., 1995). Dumont et al. (2005), Harrison et al. (2005a), and Smith et al. (2003) also state that there is still a lack of data for individual river basins, and some of the existing data may not be of high quality. Nonetheless, the empirical models available are robust enough to give insight into the spatial distribution of nutrient and carbon inputs to the ocean. Hopefully, improved temporal resolution for these data sets in a global scale (i.e. freshwater, nutrients and carbon inputs seasonal or even monthly climatology) will also allow us to assess the sub-annual impacts of riverine inputs to the ocean biogeochemistry (Harrison et al., 2005a, b) in the future.

The TODAY scenario is our best estimate of the current input of nutrients by rivers, and of the impact of these inputs on the global marine biogeochemistry (da Cunha et al., 2007). This simulation reproduces the main characteristics of ocean biogeochemistry. The tropical Atlantic surface chlorophyll a (Chla) generally matches the SeaWiFS satellite surface chlorophyll data for the same period (Fig. 3). Observed concentrations below $0.1 \mathrm{mg} \mathrm{Chl} a \mathrm{~m}^{-3}$ found in the Atlantic subtropical gyres, and the elevated ( $>2 \mathrm{mg} \mathrm{Chl} a \mathrm{~m}^{-3}$ ) concentrations found over the north Brazilian shelf are reproduced by the model (Fig. 3). On the eastern Atlantic Ocean, model results reproduce the higher limit of measured surface Chla (0.6-0.7 $\left.\mathrm{mg} \mathrm{Chl} a \mathrm{~m}^{-3}\right)$ observed at the Cape Verde Ocean Observatory $\left(17.4^{\circ} \mathrm{N}, 24.5^{\circ} \mathrm{W}\right.$ (Ye et al., 2009), and L. C. da Cunha, unpublished data, 2006-2008. Data from the Cape Verde Ocean Observatory (CVOO).). However, the model fails to reproduce the elevated concentrations ( $>1-$ $2 \mathrm{mg} \mathrm{Chl} a \mathrm{~m}^{-3}$ for the annual mean) observed in the areas off the coastal Mauritanian upwelling on the eastern Atlantic. The mean absolute error results (Table 2) suggest that modeled surface Chla is better in the TODAY scenario than in NO_RIVER, and this is reflected in modeled primary and export productions.

The simulated annual primary production (PP, $95 \%$ of which is particulate, $5 \%$ as DOM for the whole tropical Atlantic is $3.92 \mathrm{PgCa}^{-1}$, and $0.54 \mathrm{PgC} \mathrm{a}^{-1}$ corresponds to the coastal area (Table 3). In this study we have considered "coastal area" as the ocean area up to the 200m isobath. In the North Brazilian Shelf (NBS) area, modeled average primary production $\left(18 \mathrm{~mol} \mathrm{C} \mathrm{m}^{-2} \mathrm{a}^{-1}\right)$ was within the range of the measured PP values for the offshore area of the NBS $\left(4-75 \mathrm{~mol} \mathrm{C} \mathrm{m}^{-2} \mathrm{a}^{-1}\right.$, average $25 \mathrm{~mol} \mathrm{C} \mathrm{m}^{-2} \mathrm{a}^{-1}$, (Smith and Demaster, 1996)), and more recently $2-49 \mathrm{~mol} \mathrm{C} \mathrm{m}^{-2} \mathrm{a}^{-1}$, average $20 \mathrm{~mol} \mathrm{C} \mathrm{m}^{-2} \mathrm{a}^{-1}$, as fixed carbon (Subramaniam et al., 2008). Our simulated export production (EP) is $0.51 \mathrm{Pg} \mathrm{Ca}^{-1}$ for the whole tropical Atlantic, and $0.07 \mathrm{PgCa}^{-1}$ for the coastal area. In PlankTOM10, EP corresponds to the amount of particulate or-

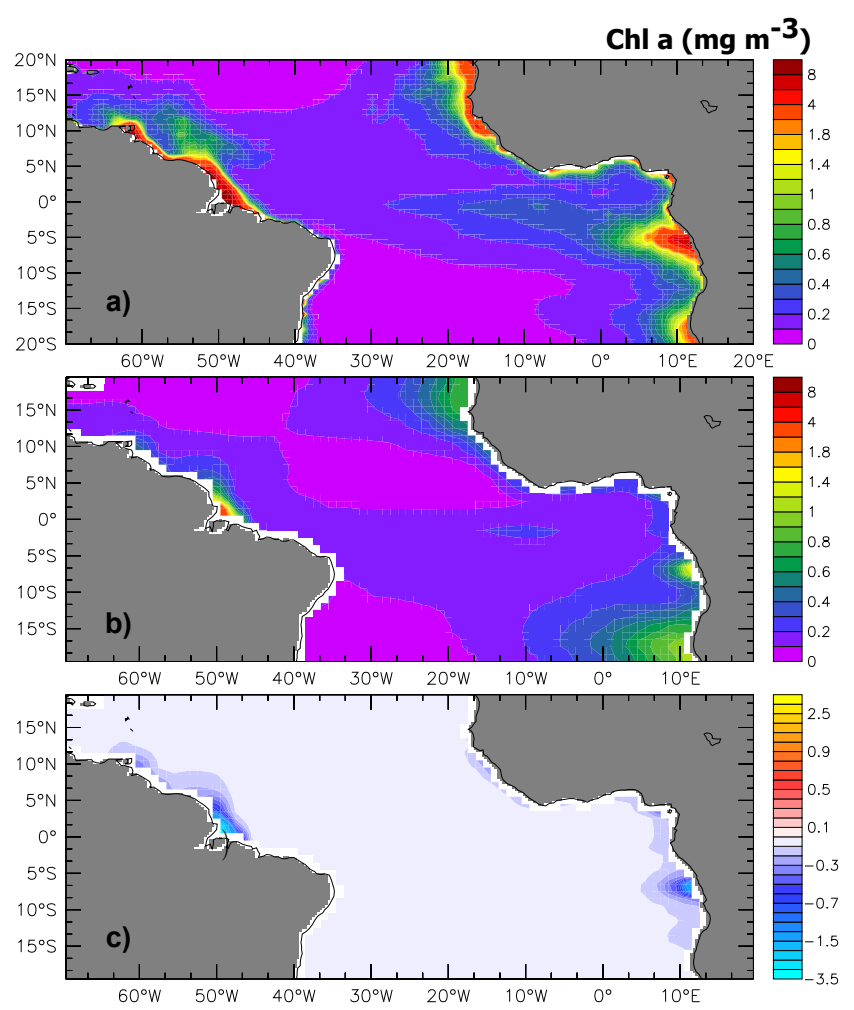

Fig. 3. Mean surface chlorophyll $a(\mathrm{Chl} a)$ in $\mathrm{mgChl} a \mathrm{~m}^{-3}$ (average 1998-2005) from (a) satellite SeaWiFS, (b) the TODAY standard scenario, and (c) difference in surface chlorophyll $a\left(\mathrm{mg} \mathrm{Chl} a \mathrm{~m}^{-3}\right)$ between the NO_RIVER and TODAY scenarios.

ganic matter exported below the euphotic zone. In this version we consider it at $100 \mathrm{~m}$. The simulated sea-to-air flux of $\mathrm{CO}_{2}$ is $0.03 \mathrm{PgC} \mathrm{a}^{-1}$ for the whole tropical Atlantic, and $5.31 \times 10^{-3} \mathrm{Pg} \mathrm{Ca}^{-1}$ for the coastal area.

Our modeled $\mathrm{CO}_{2}$ fluxes represent the equatorial outgassing associated with the upwelling, and $\mathrm{CO}_{2}$ sink regions associated with the Ogooue and Congo river outflows in the eastern tropical Atlantic (Fig. 4 and Table 4). This pattern of sink and source areas in the eastern tropical Atlantic is in agreement with the measurements of Lefèvre and Merlivat (2012), Lefèvre (2009), Lefèvre et al. (2008), and Parard et al. (2010). In the western tropical Atlantic, our modeled $\mathrm{CO}_{2}$ fluxes suggest a sink area associated with the low-salinity (SSS < 34.9) Amazon plume area, that is stronger in the winter months, in agreement with the field study of Lefèvre et al. (2010) (Table 4 and Supplement Table 1). Model results suggest a strong $\mathrm{CO}_{2}$ outgassing area at the Amazon River mouth area around $0-1^{\circ} \mathrm{N}$ latitude when river nutrients and carbon are added (TODAY and S_AMERICA scenarios). Field measurements from the SOCAT database (Pfeil et al., 2012a, b; Weiss and Goyet, 2011) show high $f \mathrm{CO}_{2}$ values in the same area (Fig. 5). A recent study by Abril et al. (2013) shows that tidal forests bordering the Amazon estuary export excess carbon mainly in the form of excess $\mathrm{CO}_{2}\left(p \mathrm{CO}_{2}\right.$ up 


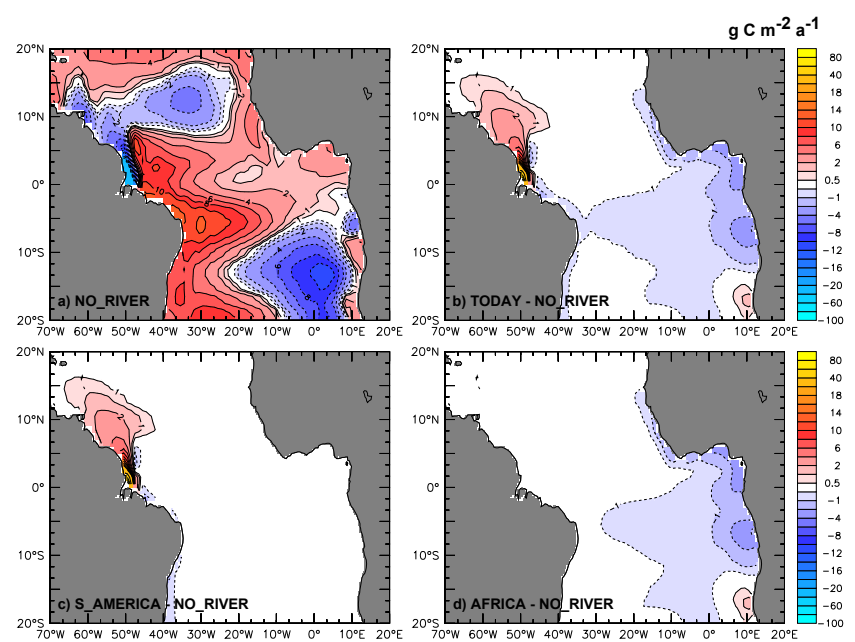

Fig. 4. Mean integrated sea-to-air $\mathrm{CO}_{2}$ flux in $\mathrm{g} \mathrm{C} \mathrm{m}^{-2} \mathrm{a}^{-1}$ (average 1998-2005) for (a) the NO_RIVER scenario. Positive values denote outgassing of $\mathrm{CO}_{2}$ from the ocean surface to the atmosphere. Plates (b), (c) and (d) represent the difference between the TODAY, S_AMERICA and AFRICA scenarios, and the NO_RIVER scenario $\left(\mathrm{g} \mathrm{C} \mathrm{m}^{-2} \mathrm{a}^{-1}\right.$, average 1998-2005). In these plates, red areas represent a decrease in the ocean $\mathrm{CO}_{2}$ sink, and blue areas represent the opposite.

to $5000 \mathrm{ppmv}$ at low tide), despite the low salinity/freshwater found in these ecosystems. The same study also reports high $p \mathrm{CO}_{2}$ values for the Amazon main stem, corroborating our modeled results of $\mathrm{CO}_{2}$ degassing in the inner Amazon shelf.

This version of the model includes $\mathrm{N}$-fixers (diazotrophs) as a plankton functional type. In the oligotrophic tropical Atlantic ocean, nitrogen fixation is an important source of new production (Subramaniam et al., 2008; Ye et al., 2012). Observations have shown that generally, despite the large variability (e.g. related to dust deposition events; Fernández et al., 2010; Voss, 2004), N-fixation rates are larger in the western tropical than in the eastern tropical Atlantic (Reynolds et al., 2007). The simulated annual atmospheric N-fixation by diazotrophs for the whole study area is $9.93 \mathrm{Tg} \mathrm{Na}^{-1}$ $\left(0.71 \mathrm{Tmol} \mathrm{Na}^{-1}\right)$ and occurs mainly off the coastal zone (1.15 $\mathrm{Tg} \mathrm{N} \mathrm{a}^{-1}$, N-fixation rate for the coastal tropical Atlantic). In the TODAY scenario, the western tropical Atlantic and the southern gyre are, on average, the areas where $\mathrm{N}$ fixation is most intense (Fig. 6). In the low surface salinity area ( $\mathrm{SSS}<34.9$, corresponding to $\sim 1.2 \times 10^{6} \mathrm{~km}^{-1}$ ) of the western tropical Atlantic, our modeled average $\mathrm{N}$-fixation rate is $35.8 \mathrm{mmol} \mathrm{N} \mathrm{m}^{-2} \mathrm{a}^{-1}$. In situ (Amazon River plume) $\mathrm{N}$-fixation rates measured by Subramaniam et al. (2008) varied between 9.13 and $359.9 \mathrm{mmol} \mathrm{N} \mathrm{m}^{-2} \mathrm{a}^{-1}$. Model results suggest that denitrification occurs only at subsurface $(-10 \mathrm{~m})$ in the coastal area adjacent to the Amazon river outflow, at an average rate of $\sim 8.3 \mathrm{mmol} \mathrm{N} \mathrm{m}^{-2} \mathrm{a}^{-1}$. Given the modeled high riverine nutrient inputs and primary production in the

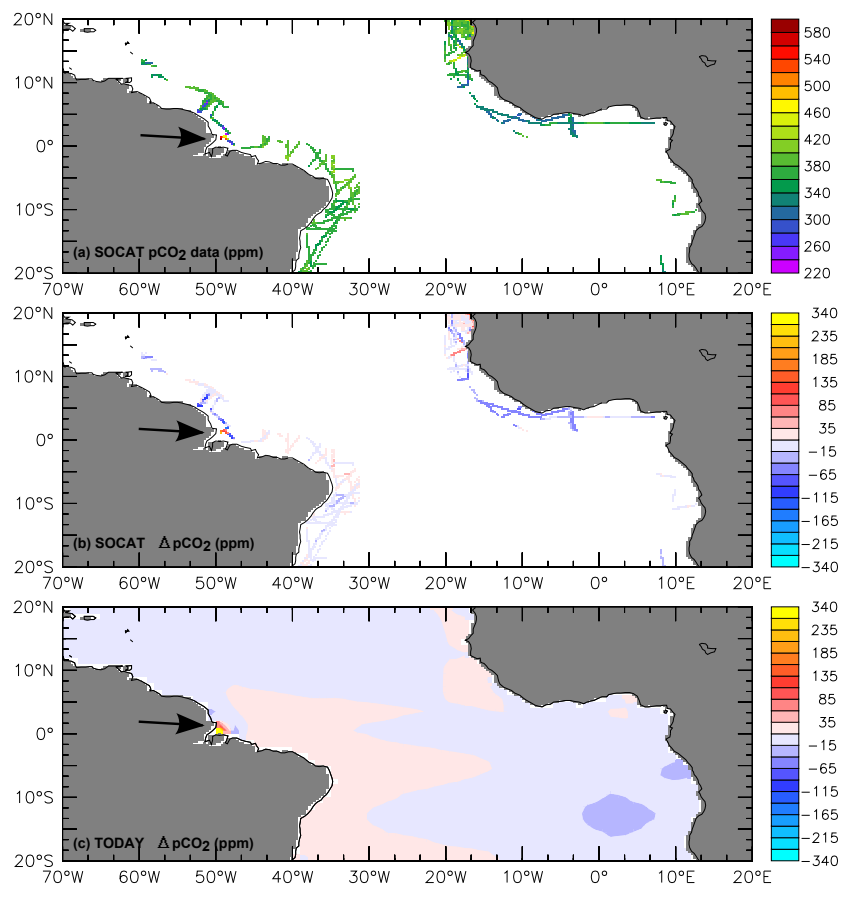

Fig. 5. (a) Coastal surface seawater $p \mathrm{CO}_{2}$ data (in ppm) (a) from the SOCAT database (Pfeil et al., 2012b), (b) $\Delta p \mathrm{CO}_{2}$ (SOCAT - atmospheric $p \mathrm{CO}_{2}$ from Ragged Point station, Barbados (373 ppm)), (c) $\triangle p \mathrm{CO}_{2}$ from the TODAY scenario (average 1998-2005). The black arrow indicates the high $\mathrm{CO}_{2}$ area in the Amazon River mixing zone (SOCAT data from December 1982).

same area, the denitrification rate is not enough to decrease the biologically driven OM fixation.

Our modeled $\mathrm{N}$-fixation rates in the southern tropical Atlantic gyre (ca. $0.7 \mathrm{~g} \mathrm{~N} \mathrm{~m}^{-2} \mathrm{a}^{-1}$ ) are comparable to those modeled by Monteiro et al. (2010), using the MIT selfassembling ocean ecosystem model (ca. $0.5 \mathrm{~g} \mathrm{~N} \mathrm{~m}^{-2} \mathrm{a}^{-1}$, considering the sum of all nitrogen-fixing plankton types), and by Moore et al. (2004), using a biogeochemistryecosystem ocean model (ca. $0.4 \mathrm{~g} \mathrm{~N} \mathrm{~m}^{-2} \mathrm{a}^{-1}$ ). They are lower than those estimated by Deutsch et al. (2007), using excess phosphorus $\left(\mathrm{P}^{*}\right)$ distribution (ca. $1.7 \mathrm{~g} \mathrm{~N} \mathrm{~m}^{-2} \mathrm{a}^{-1}$ ). This issue is still to be resolved, since the field data from the repeated AMT cruises from 1995-1999 reveal very low abundance of N-fixing cyanobacteria Trichodesmium sp. in the southern tropical Atlantic (Tyrrell et al., 2003). There is also, unfortunately, a lack of (climatology-like) field date on $\mathrm{N}$-fixation rates for this area, as also pointed out by Monteiro et al. (2010), while validating their model results. The most up-to-date estimates of $\mathrm{N}$-fixation in this area have been recently compiled by the MAREDAT effort (Buitenhuis et al., 2013a), and the in situ N-fixation rates, measured in November (2001 and 2007) are one order of magnitude lower $\left(0.01-0.07 \mathrm{~g} \mathrm{~N} \mathrm{~m}^{-2} \mathrm{a}^{-1}\right.$, or 2-14 $\mathrm{M} \mathrm{N} \mathrm{N} \mathrm{m}^{-2} \mathrm{~d}^{-1}$, measured as whole seawater $\mathrm{N}$-fixation rate using ${ }^{15} \mathrm{~N}$; Luo et al., 2012). Finally, Carpenter and Capone (2008) state that there 
Table 3. Primary production (PP) and export production (EP) in $\mathrm{PgCa}^{-1}$, sea-to-air $\mathrm{CO}_{2}$ fluxes $(\mathrm{CFLX})$ in $\mathrm{TgCa} \mathrm{Ca}^{-1}$, and $\mathrm{N}_{2}$-fixation (NFIX) rates in $\mathrm{Tg} \mathrm{N} \mathrm{a}^{-1}$, for each scenario considering the whole and coastal tropical Atlantic Ocean $\left(20^{\circ} \mathrm{S}-20^{\circ} \mathrm{N}, 70^{\circ} \mathrm{W}-20^{\circ} \mathrm{E}\right)$. The columns in italics correspond to the difference ("Diff", in $\mathrm{Pg} \mathrm{Ca}^{-1}$ or $\mathrm{Tg} \mathrm{Ca}^{-1}$ ) between the TODAY, S_AMERICA, AFRICA scenarios and the NO_RIVER scenario. The numbers in parenthesis correspond to the change in \% relative to the NO_RIVER scenario ((() scenario NO_RIVER) $\times 100$ )/NO_RIVER) - 100). Positive values for CFLX denote outgassing of $\mathrm{CO}_{2}$ to the atmosphere.

\begin{tabular}{lcccccccl}
\hline Scenario & PP & Diff $(\%)$ & EP & Diff $(\%)$ & CFLX & Diff $(\%)$ & NFIX & Diff (\%) \\
\hline \multicolumn{7}{l}{ Whole tropical Atlantic Ocean } \\
\hline NO_RIVER & 3.51 & & 0.47 & & 37.13 & & 9.93 & \\
TODAY & 3.92 & $0.41(12)$ & 0.51 & $0.046(10)$ & 32.01 & $-5.12(-14)$ & 11.08 & $1.15(12)$ \\
S_AMERICA & 3.73 & $0.23(6)$ & 0.493 & $0.025(5)$ & 39.96 & $2.83(8)$ & 10.63 & $0.7(7)$ \\
AFRICA & 3.71 & $0.20(6)$ & 0.489 & $0.022(5)$ & 29.46 & $-7.67(-21)$ & 10.52 & $0.59(6)$ \\
\hline Coastal tropical Atlantic Ocean & & & & & & \\
\hline NO_RIVER & 0.40 & & 0.057 & & 3.87 & & 1.04 & \\
TODAY & 0.54 & $0.14(34)$ & 0.074 & $0.017(30)$ & 5.31 & $1.44(37)$ & 1.15 & $0.11(10)$ \\
S_AMERICA & 0.50 & $0.10(24)$ & 0.068 & $0.011(19)$ & 6.48 & $2.61(67)$ & 1.19 & $0.15(14)$ \\
AFRICA & 0.44 & $0.04(10)$ & 0.063 & $0.006(11)$ & 2.91 & $-0.97(-25)$ & 1.02 & $-0.02(-2)$ \\
\hline
\end{tabular}

Table 4. Modeled regional sea-to-air $\mathrm{CO}_{2}$ fluxes (CFLX, in $\mathrm{Tg} \mathrm{Ca}^{-1}$ ) and $\mathrm{N}$-fixation (NFIX, in $\mathrm{Tg} \mathrm{Na}^{-1}$ ) in the western (lat: $0^{\circ}: 10^{\circ} \mathrm{N}$, lon: $60^{\circ} \mathrm{W}: 30^{\circ} \mathrm{W}$ ) and eastern tropical Atlantic Ocean (lat: $10^{\circ} \mathrm{S}: 7^{\circ} \mathrm{N}$, lon: $10^{\circ} \mathrm{W}: 5^{\circ} \mathrm{E}$ ).

\begin{tabular}{lrrrr}
\hline & \multicolumn{3}{c}{ Western Atlantic Ocean (latitude $0-10^{\circ} \mathrm{N}$, longitude $\left.60^{\circ} \mathrm{W}-30^{\circ} \mathrm{W}\right)$} \\
\hline Scenario & $\begin{array}{r}\text { CFLX } \\
\text { (all salinities) }\end{array}$ & $\begin{array}{r}\text { CFLX } \\
(\mathrm{SSS} \leq 34.9)\end{array}$ & $\begin{array}{r}\text { NFIX } \\
\text { (all salinities) }\end{array}$ & $\begin{array}{r}\text { NFIX } \\
(\mathrm{SSS} \leq 34.9)\end{array}$ \\
\hline NO_RIVER & 12.93 & -3.44 & 2.92 & 0.57 \\
TODAY & 9.21 & 0.53 & 3.20 & 0.70 \\
\hline & Eastern tropical Atlantic (latitude $10^{\circ} \mathrm{S}-7^{\circ} \mathrm{N}$, longitude $\left.10^{\circ} \mathrm{W}-5^{\circ} \mathrm{E}\right)$ \\
\hline & CFLX & CFLX & NFIX & NFIX \\
& (all salinities) & (SSS $\leq 34)$ & $($ all salinities $)$ & $(\mathrm{SSS} \leq 34)$ \\
\hline NO_RIVER & 0.11 & -0.16 & 1.12 & 0.20 \\
TODAY & -3.45 & -1.06 & 1.13 & 0.18 \\
\hline
\end{tabular}

is still room to improve our knowledge of the spatial and temporal distribution of nitrogen fixation in the world ocean.

\subsection{Impact of rivers on the tropical Atlantic Ocean biogeochemistry}

The impact of rivers on the tropical Atlantic biogeochemistry can be assessed by subtracting the NO_RIVER scenario from the TODAY scenario. This comparison allows us to identify the features in the tropical Atlantic Ocean biogeochemistry that are caused by river nutrient fluxes $\left(70^{\circ} \mathrm{W}-20^{\circ} \mathrm{E}, 20^{\circ} \mathrm{S}-\right.$ $\left.20^{\circ} \mathrm{N}\right)$. The differences in both scenarios between PP, EP, sea-air $\mathrm{CO}_{2}$ flux, and nitrogen fixation for the whole tropical Atlantic Ocean and its coastal area are listed in Table 3.

When riverine inputs are added, the model reproduces the patterns of high primary production (PP) adjacent to the large rivers outflow (Fig. 7) well. Increased nutrient availability from riverine input in the Tropical Atlantic (TODAY
- NO_RIVER) leads to an increase of $0.41 \mathrm{Pg} \mathrm{C} \mathrm{a}^{-1}$ in open ocean primary production ( $+12 \%$ relative to NO_RIVER), and $0.14 \mathrm{Pg} \mathrm{Ca}^{-1}$ in coastal ocean primary production (+34\% relative to NO_RIVER). The increase in primary production is noticeable in coastal and open ocean areas adjacent to the Amazon and Orinoco outflows, and in open ocean eastwards of the Congo outflow (Fig. 7), and in the Gulf of Guinea. We estimate a modest increase in the open ocean export production (EP) in the TODAY scenario, $4.61 \times 10^{-2} \mathrm{Pg} \mathrm{Ca}^{-1}(+10 \%)$. The increase in coastal EP is small in its absolute value $\left(1.69 \times 10^{-2} \mathrm{Pg} \mathrm{C} \mathrm{a}^{-1}\right)$ but represents a $30 \%$ increase relative to the NO_RIVER scenario.

River nutrient inputs also impact phytoplankton composition in the TODAY scenario because nutrient limitation is alleviated in the coastal ocean (mainly $\mathrm{N}$ and $\mathrm{Fe}$ ), considering the amounts of delivered nutrients by rivers and the corresponding coastal ocean EP (Table 5). Surface chlorophyll associated to diatoms (silicifiers) has the largest 
Table 5. Modeled coastal ocean $\mathrm{EP}(\mathrm{N}$ and $\mathrm{Fe})$, riverine inputs $(\mathrm{N}$ and $\mathrm{Fe})$ and ratios ${ }^{\mathrm{a}}$ between riverine inputs and $\mathrm{EP}$ in the tropical Atlantic Ocean $\left(20^{\circ} \mathrm{S}-20^{\circ} \mathrm{N}, 70^{\circ} \mathrm{W}-20^{\circ} \mathrm{E}\right)$.

\begin{tabular}{|c|c|c|c|c|c|c|c|c|c|c|c|}
\hline \multirow[b]{2}{*}{ Simulation } & \multicolumn{4}{|c|}{ Coastal ocean export production } & \multicolumn{4}{|c|}{ River nutrient inputs } & \multicolumn{3}{|c|}{ River: coastal EP ratio } \\
\hline & $\begin{array}{l}\text { EP } \\
\text { Tmol C a }^{-1}\end{array}$ & $\begin{array}{l}\mathrm{EP}^{\mathrm{b}} \\
\mathrm{Tmol} \mathrm{N} \mathrm{a}^{-1}\end{array}$ & $\begin{array}{l}\mathrm{EP}^{\mathrm{b}} \\
\mathrm{Gmol} \mathrm{Fe} \mathrm{a}^{-1}\end{array}$ & $\begin{array}{l}\mathrm{EP}^{\mathrm{b}} \\
\mathrm{Gmol} \mathrm{Pa}^{-1}\end{array}$ & $\begin{array}{l}\text { River } \mathrm{C}^{\mathrm{c}} \\
\text { Tmol C } \mathrm{a}^{-1}\end{array}$ & $\begin{array}{l}\text { River } \mathrm{N} \\
\text { Tmol } \mathrm{N} \mathrm{a}^{-1}\end{array}$ & $\begin{array}{l}\text { River Fe } \\
\text { Gmol Fe } \mathrm{a}^{-1}\end{array}$ & $\begin{array}{l}\text { River } \mathrm{P} \\
\text { Gmol } \mathrm{P} \mathrm{a}^{-1}\end{array}$ & $\begin{array}{l}\text { River: EP } \\
\mathrm{N}\end{array}$ & $\begin{array}{l}\text { River: EP } \\
\text { Fe }\end{array}$ & $\begin{array}{l}\text { River: EP } \\
\mathrm{P}\end{array}$ \\
\hline NO_RIVER & 4.75 & 0.62 & 0.02 & 38.9 & 0 & 0 & 0 & 0 & 0 & 0 & 0 \\
\hline TODAY & 6.16 & 0.81 & 0.03 & 50.5 & 6.75 & 1.09 & 0.45 & 10.97 & 135 & 1461 & 21.7 \\
\hline S_AMERICA & 5.67 & 0.74 & 0.03 & 46.4 & 5.09 & 0.77 & 0.33 & 5.44 & 104 & 1165 & 11.7 \\
\hline AFRICA & 5.67 & 0.69 & 0.03 & 43.2 & 1.66 & 0.32 & 0.12 & 5.54 & 46 & 455 & 12.8 \\
\hline
\end{tabular}

${ }^{a}$ The ratio gives an estimate of the how much of the coastal EP is supported by riverine nutrients, ${ }^{b} \mathrm{~N}, \mathrm{P}$ and Fe coastal ocean EP values were estimated using the model molar ratios of $\mathrm{C}: \mathrm{N}: \mathrm{P}(122: 16: 1)$, and $\mathrm{C}: \mathrm{Fe}\left(1: 5 \times 10^{-6}\right),{ }^{\mathrm{c}}$ River carbon inputs are the sum of dissolved (DOM) and particulate organic carbon (POM).

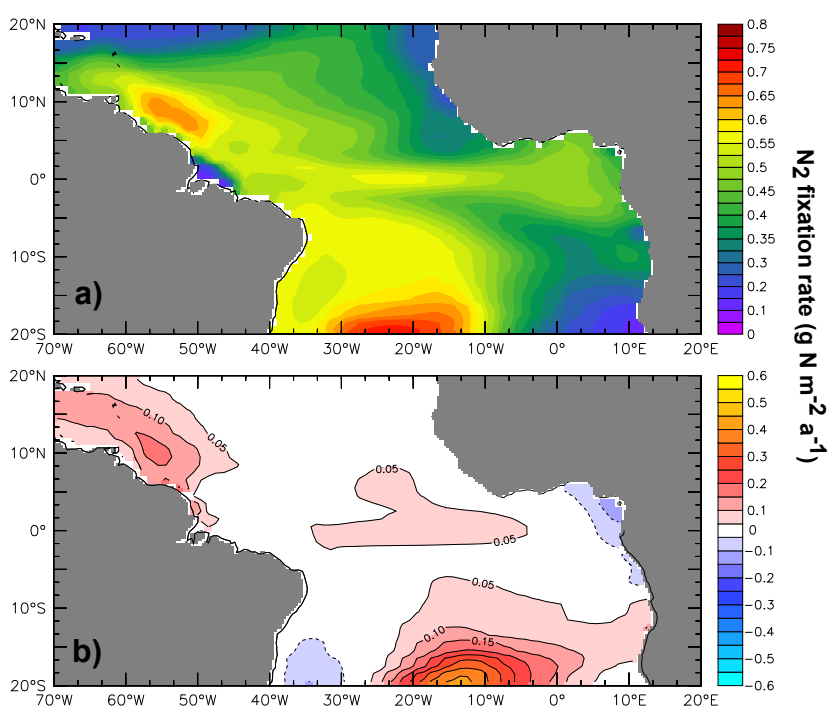

Fig. 6. Mean $\mathrm{N}$-fixation rates in $\mathrm{g} \mathrm{N} \mathrm{m}^{-2} \mathrm{a}^{-1}$ (average 1998-2005): (a) the TODAY scenario, (b) Difference between the TODAY and NO_RIVER scenarios.

relative increase in the whole tropical Atlantic when compared to the NO_RIVER scenario, mainly in the coastal and near-coastal ocean area (Supplement Fig. 1). The contribution of diatom-chlorophyll to total modeled surface chlorophyll increases from $6 \%$ to $14 \%$ in the coastal tropical Atlantic (Supplement Table 2), reproducing the larger abundance of diatoms in coastal areas, where there is larger abundance of nutrients (Humborg et al., 2000; Subramaniam et al., 2008). In addition to comparing how much export production can be maintained by river inputs in the coastal ocean, we have represented the surface DIN, Si and Fe concentrations in Fig. 8, highlighting the change (the TODAY scenario minus NO_RIVER) of the concentration contour line relative to the half-saturation growth constants $\left(K_{\mathrm{m}}\right)$ for diatoms. Considering the model values of diatoms $K_{\mathrm{m}}$ for nitrate $\left(K_{\mathrm{m}}=2 \mu \mathrm{M}\right)$, silicate $\left(K_{\mathrm{m}}=0.42 \mu \mathrm{M}\right)$, and iron ( $\left.K_{m}=0.17 \mathrm{nM}\right)$, we have plotted over the surface nutrient concentration in the TODAY scenario: (i) red areas if the surface nutrient concentration has dropped below the respective $K_{\mathrm{m}}$ threshold contour (TODAY - NO_RIVER) (red ar- eas in the map give a rough indication where nutrient limitation for diatoms may have become more severe in the TODAY scenario, compared to NO_RIV); and (ii) purple areas if the surface nutrient concentration is above the respective $K_{\mathrm{m}}$ threshold contour (TODAY - NO_RIVER). Purple areas in the map denote the opposite (alleviation of limiting conditions) of red areas. As in da Cunha et al. (2007), we have decided to plot the change in the surface contour lines corresponding to PlankTOM $K_{\mathrm{m}}$ values for diatoms, because they have lower surface-to-volume ratios compared to nano- or pico-phytoplankton. Thus they need nutrientricher conditions for growth in contrast to smaller phytoplankton, and generally dominate the phytoplankton community under high-nutrient condition. The smaller phytoplankton groups have higher surface-to-volume ratios, allowing a better exploitation of low nutrient concentrations (Sarthou et al., 2005). Model results suggest that river nutrient inputs alleviate inorganic nitrogen and $\mathrm{Si}$ limitation for diatoms in areas close to the large rivers, but a band of increased Fe limitation extends in the southeastern tropical Atlantic (Fig. 8). River inputs enhance PP in coastal areas but may deplete nutrients in surface waters off in the ocean gyres because of higher vertical export of organic matter before the water masses reach these areas, as suggested in previous studies using ocean biogeochemistry models (da Cunha et al., 2007; Giraud et al., 2008). The increase in Fe limitation is coherent with the large increase in modeled surface chlorophyll a, and especially the fraction associated with diatoms in the coastal ocean in the TODAY scenario, and with the slight increase in $\mathrm{N}$-fixation (diazotrophs also require $\mathrm{Fe}$ for growth) in the surface layers (Fig. 6).

Diazotroph-associated chlorophyll increases in areas further off the coastal ocean, where $\mathrm{Si}$ and $\mathrm{N}$ become limiting to diatoms. Results shown in Tables 3 and 4 suggest that most of the nitrogen fixation in the tropical Atlantic occurs in the open ocean. For the tropical Atlantic (whole and coastal ocean), model results suggest that the increase in N-fixation relative to the NO_RIVER scenario is proportional to the increase in PP and EP. Thus, the amount of PP and EP supported by N-fixation remains unchanged for the NO_RIVER and TODAY simulations, i.e. $1.9 \%$ and $14 \%$, respectively (Supplement Tables 3 to 5). Coastal ocean 


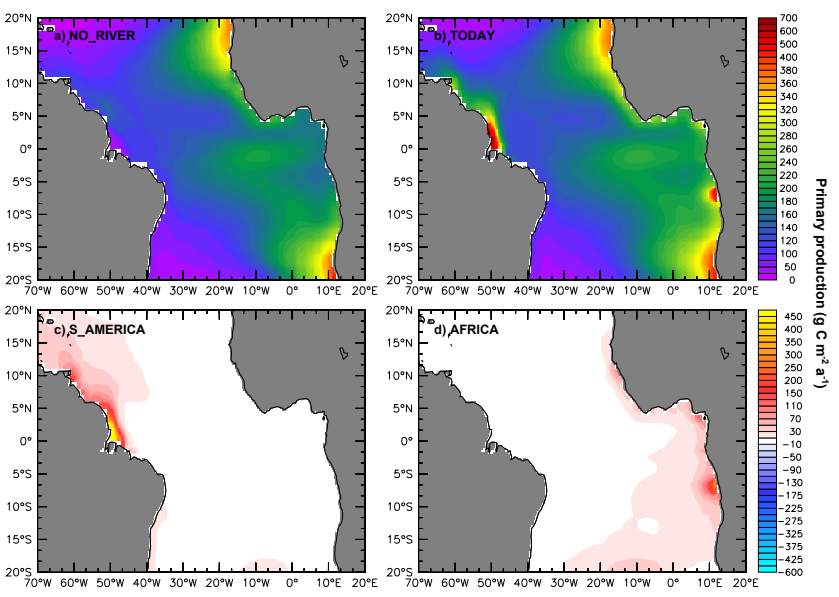

Fig. 7. Mean fields of integrated primary production (PP) in $\mathrm{g} \mathrm{C} \mathrm{m}^{-2} \mathrm{a}^{-1}$ (average 1998-2005) (a) NO_RIVER scenario, (b) the TODAY scenario, (c) difference between the S_AMERICA and NO_RIVER scenarios, and (d) difference between the AFRICA and NO_RIVER scenarios.

$\mathrm{N}$-fixation slightly decreases in the TODAY scenario, as well as the modeled surface chlorophyll concentrations associated to diazotrophs, concomitant to the increase in diatomassociated chlorophyll in this area. N-fixation in the whole tropical Atlantic is $\sim 0.62 \mathrm{Tmol} \mathrm{Ca}^{-1}$ higher in the TODAY scenario (compared to NO_RIVER). This value is slightly higher than the decrease in sea-air $\mathrm{CO}_{2}$ fluxes (outgassing) in the TODAY scenario by $\sim 0.43 \mathrm{Tmol} \mathrm{Ca}^{-1}$, suggesting that $\mathrm{N}$-fixation also plays a role in controlling these fluxes in the tropical Atlantic, especially in its western portion (Subramaniam et al., 2008).

Sea-to-air $\mathrm{CO}_{2}$ fluxes for the whole tropical Atlantic ocean decrease by $5.12 \times 10^{-3} \mathrm{PgCa}^{-1}(-14 \%$, Table 3 and Fig. 4), corresponding to the relative increase in PP and EP for the whole tropical Atlantic. However, in the coastal area, model results suggest an increase in sea-to-air $\mathrm{CO}_{2}$ fluxes relative to NO_RIVER by $+37 \%\left(1.44 \times 10^{-3} \mathrm{PgC} \mathrm{a}^{-1}\right)$. Model results (PISCES-T) from da Cunha et al. (2007) suggest that increased river nutrient, DIC and OM inputs in the coastal ocean enhance PP and EP, and, concomitantly, the remineralization of the new production, increasing sea-to-air $\mathrm{CO}_{2}$ fluxes. This will be further discussed in Sects. 3.2.1. and 3.3.1. The $\mathrm{CO}_{2}$ outgassing associate to the equatorial upwelling is not affected by riverine inputs (Fig. 4).

Model results suggest that shutting down river nutrients and carbon inputs (NO_RIVER scenario) leads to smaller rates of primary productivity, and, in consequence, export production. We have tested the change in the biological pump efficiency $\left(E_{\mathrm{BP}}\right)$ between the NO_RIVER and TODAY scenarios. $E_{\mathrm{BP}}$ is defined as the ratio between the concentration of residual nutrients in surface waters and the concentration of nutrients in deeper waters (Eq. 2, according to Sarmiento
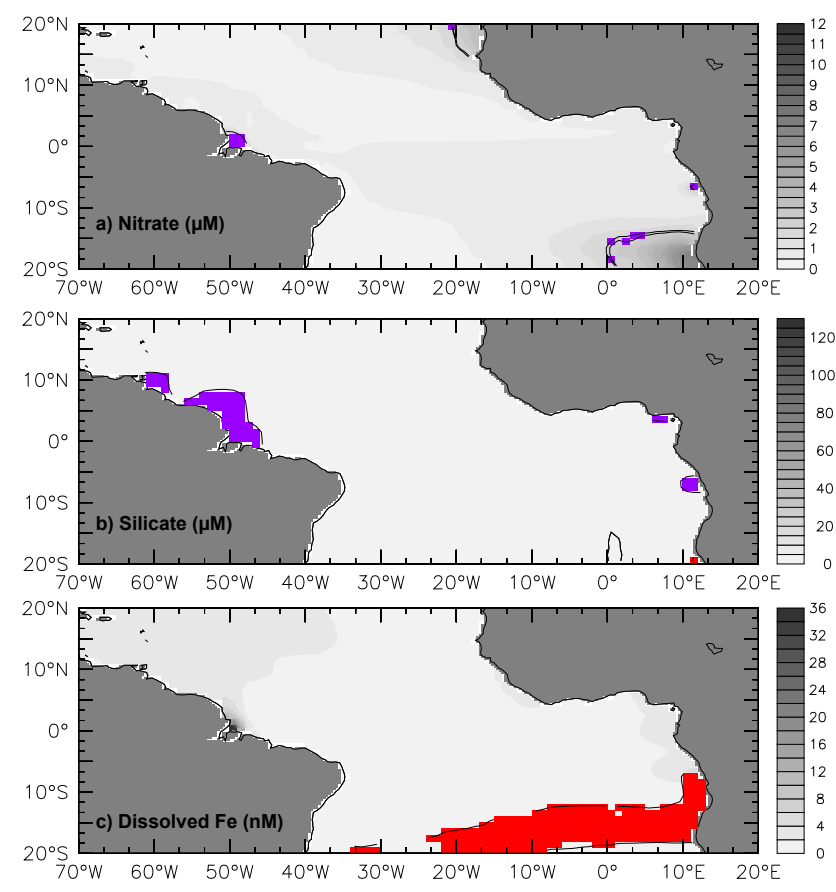

Fig. 8. Surface mean fields (average 1998-2005) from the TODAY standard scenario for (a) $\mathrm{NO}_{3}$ in $\mu \mathrm{M}$, (b) $\mathrm{Si}$ in $\mu \mathrm{M}$, and (c) Fe in $\mathrm{nM}$. Red areas correspond to regions where surface nutrient concentration in the TODAY scenario drops below the threshold contour of diatoms $K_{\mathrm{m}}$ (half saturation growth constant) when compared to the NO_RIVER scenario. Purple areas show the reverse. Thresholds are set to (a) $2.0 \mu \mathrm{M} \mathrm{NO}_{3}$, (b) $0.42 \mu \mathrm{M} \mathrm{Si}$, and (c) $0.17 \mathrm{nM} \mathrm{Fe}$. Red areas give a rough indication where diatom nutrient limitation has become more severe. Purple areas correspond to regions where diatom nutrient limitation has been alleviated.

and Gruber 2006):

$E_{\mathrm{BP}}=\frac{C_{\text {deep }}-C_{\text {surf }}}{C_{\text {deep }}}$,

where $C_{\text {deep }}$ is the modeled average nitrate concentration between $100 \mathrm{~m}$ and $200 \mathrm{~m}$, and $C_{\text {surf }}$ is the modeled average nitrate concentration between $0 \mathrm{~m}$ and $100 \mathrm{~m}$. In the western tropical Atlantic, modeled $E_{\mathrm{BP}}$ is relatively high in both scenarios, except in the continental shelf areas receiving large inputs of river nutrients and carbon (the TODAY scenario, Fig. 9). In the TODAY and S_AMERICA scenarios, the amount of river $\mathrm{N}$ and $\mathrm{Fe}$ input is large enough to support the coastal ocean export production on the western Atlantic (Table 5), but despite the high primary productivity and export, $E_{\mathrm{BP}}$ is low, characterizing a regional efficient regeneration loop for the organic matter. At a first glance, this may seem a paradox considering the modeled increase $(+30 \%)$ in export production, and the large relative increase in $\mathrm{Chl} a$ associated to diatoms ( $6 \%$ to $14 \%$ of the total surface chlorophyll concentration) for the coastal ocean when river nutrients are added to the model. However, when river nutrients are added 

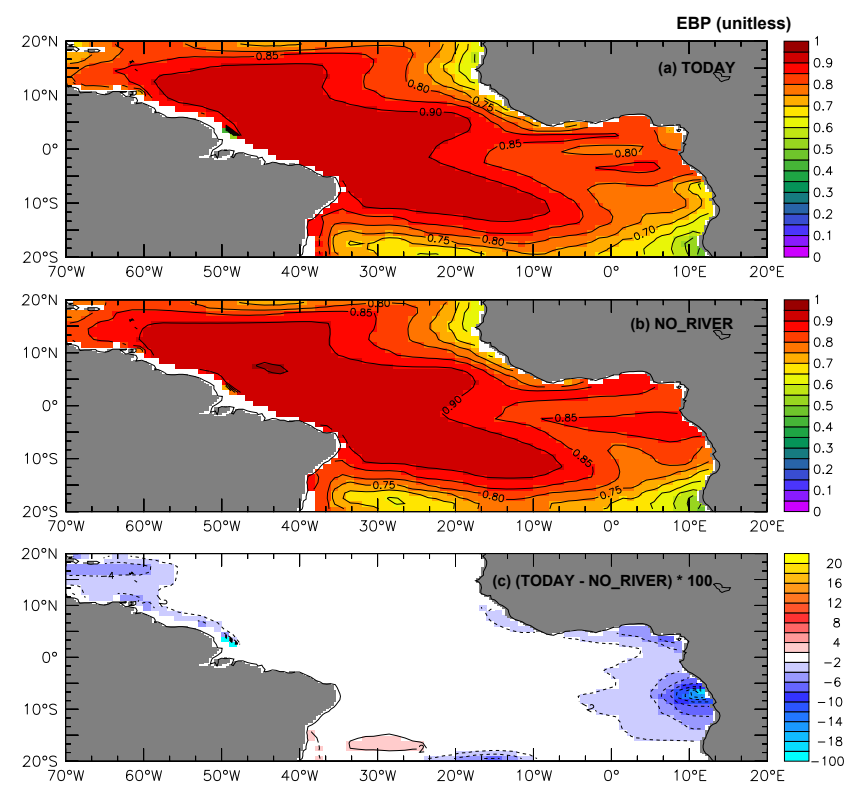

Fig. 9. Mean biological pump efficiency ( $E_{\mathrm{BP}}$, average 1998-2005) (a) the TODAY scenario, (b) the NO_RIVER scenario, and (c) difference in \% between the TODAY and NO_RIVER scenarios.

to the model, there is also, on average, more nutrient availability in the first $100 \mathrm{~m}$ close to river outflows due to inputs and enhanced export production. This further explains the lower $E_{\mathrm{BP}}$ values when river nutrients are included in the model. Thus, one may conclude that in the tropical Atlantic a large portion of the primary production may be recycled in the upper layers of the narrow ocean areas adjacent to large river outflows.

\subsubsection{Impact of South American rivers}

Our results in the S_AMERICA scenario suggest an increase in primary production along the South American shelf and adjacent ocean areas, and no changes on the Eastern tropical Atlantic (compared to NO_RIVER, Fig. 7). The modeled primary production in the open and coastal ocean is $3.73 \mathrm{Pg} \mathrm{Ca}^{-1}$ and $0.54 \mathrm{PgCa}^{-1}$, respectively. The relative change in PP between the S_AMERICA and NO_RIVER scenarios corresponds to an increase in $6 \%$ and $24 \%$ for the open and coastal ocean, respectively. These changes are only noticeable off the northern coast in South America, adjacent to the main river outflows.

The western tropical Atlantic receives more river nutrients and carbon compared to the eastern side (Table 1). In this study, our sensitivity tests suggest that South American rivers have the same relative impact (compared to simulation NO_RIVER) in PP and EP for the whole tropical Atlantic, but have an impact twofold larger than African rivers on coastal primary and export production (Tables 3 and 4). River nutrients and carbon impact the sea-to-air $\mathrm{CO}_{2}$ fluxes differently: the relative increase in EP $(+5.4 \%)$ for the whole tropical Atlantic is comparable to the relative increase in seato-air $\mathrm{CO}_{2}$ flux $(+7.6 \%)$. The increase in primary production is proportional to the increase in export production in the western tropical Atlantic Ocean, but the riverine inputs are insufficient to decrease or to revert the sea-to-air $\mathrm{CO}_{2}$ flux in the coastal area. Although the $\mathrm{CO}_{2}$ sink region in the western Atlantic is present in this scenario, the sink in the eastern tropical Atlantic is smaller when African rivers are not included in the model, thus keeping the $\mathrm{CO}_{2}$ fluxes comparable to the NO_RIVER scenario (Table 4 and Fig. 4). Finally, our model results suggest that, in the western tropical Atlantic, almost all $\mathrm{CO}_{2}$ outgassing occurs in the coastal ocean area $\left(2.8 \mathrm{Tg} \mathrm{Ca}^{-1}\right.$, whole tropical Atlantic, and $2.6 \mathrm{Tg} \mathrm{C} \mathrm{a}^{-1}$, coastal tropical Atlantic Ocean, Table 3), very close to the Amazon river outflow (Figs. 4 and 5). These numbers are obtained by subtracting the NO_RIVER sea-to-air $\mathrm{CO}_{2}$ fluxes from those of the S_AMERICA scenario, and correspond to ca. $50 \%$ of the riverine OM input to the western tropical Atlantic (the S_AMERICA scenario, Table 1). As stated in da Cunha et al. (2007), the model resolution does not allow coastal water entrapment, and part of the riverine OM (mainly the particulate $\mathrm{OM}$ ) and DIC rapidly return to the atmosphere as $\mathrm{CO}_{2}$. In PlankTOM10, marine and terrestrial OM have the same degradation rates. On the one hand, field studies have shown that riverine OM may be refractory and may not provide an "immediate" source of new nutrients to coastal plankton (Dittmar and Kattner, 2003; Hansell et al., 2004). On the other hand, in areas heavily impacted by human activity (e.g. domestic sewage), river OM may have an important anthropogenic fraction, more labile, and thus more easily exported as $\mathrm{CO}_{2}$ to the coastal ocean (Harrison et al., 2005a; Meybeck, 2004). A model-based study in the Arctic assessed the impact of riverine dissolved OM to the regional biogeochemistry, considering a different lability to terrestrial OM (Manizza et al., 2011). This study results suggest that river OM inputs may decrease the Arctic Ocean $\mathrm{CO}_{2}$ sink by $\sim 10 \%$.

Our results also suggest that the South American rivers, especially the Amazon and Orinoco, further influence primary production in areas in the Caribbean Sea (not shown), in agreement with field measured data (nutrients and chlorophyll a) from Corredor et al. (2003). In the TODAY and S_AMERICA scenarios, both regional primary and export production in the Caribbean Sea increase by about $+70 \%$, compared to the NO_RIVER scenario. Finally, this study suggests that on the western tropical Atlantic, except in the coastal areas off the Amazon and Orinoco plumes, coastal PP does not increase much (Fig. 7). The north-eastern Brazilian shelf is very narrow, characterized by oligotrophic waters and little freshwater inputs. Consequently, the small river nutrient inputs are not sufficient to trigger a "fertilizing effect" such as off the Amazonian shelf. 


\section{River nutrients and the sea-to-air $\mathrm{CO}_{2}$ flux in the western tropical Atlantic}

Körtzinger (2003) identified an area strongly undersaturated with respect to atmospheric $\mathrm{CO}_{2}$ associated with the amazon River plume (at latitude $10^{\circ} \mathrm{N}$, longitude $50^{\circ} \mathrm{W}-48^{\circ} \mathrm{W}$ ). This local $\mathrm{CO}_{2}$ sink is due to a combination of physical (mixing effect of river- and seawater in the plume) and biological (production in the plume) effects. Here we compare the TODAY and NO_RIVER scenarios to assess the role of river nutrients and carbon in the modeled sea-to-air fluxes at the Amazon plume area (latitude 0 to $10^{\circ} \mathrm{N}$, longitude 60 to $30^{\circ} \mathrm{W}$ ). Our model results (average 1998-2005) suggest that in the western tropical Atlantic, surface waters north of $3^{\circ} \mathrm{N}$ are undersaturated with respect to atmospheric $\mathrm{CO}_{2}$, and the sea-to-air $\mathrm{CO}_{2}$ flux is negative (Figs. 4 and 5), in agreement with the measurements made by Körtzinger (2003).

In the western tropical Atlantic between latitudes 0 and $3^{\circ} \mathrm{N}$, our model results suggest that in the TODAY scenario, river carbon inputs (DIC, DOM, POM) reverse the undersaturation of $\mathrm{CO}_{2}$ in surface seawater caused by the low salinity surface waters (physical effect), despite the large increase in primary production compared to simulation TODAY (Fig. 4). Chen et al. (2012) state that the process above explains why tropical estuaries are often sources of $\mathrm{CO}_{2}$ to the atmosphere. Our results are also supported by an increase in modeled alkalinity and DIC concentrations in surface waters. Surface calcifier-chlorophyll also increases up to $40 \%$ in the same area. In our simulations, river OM, despite acting as additional nutrient sources, is insufficient to decrease the mineralization of organic matter and consequently seato-air $\mathrm{CO}_{2}$ fluxes are on average positive. Local river DIC input (mainly Amazon and Tocantins Rivers) corresponds to $40 \mathrm{Tg} \mathrm{Ca}{ }^{-1}$, which also explains the surface $\mathrm{CO}_{2}$ supersaturation close to the outflow. Field data (Weiss and Goyet, 2011; Weiss, 2011) collected in December 1982 and available from the SOCAT database (Pfeil et al., 2012b) (low outflow season) show high $\mathrm{fCO}_{2}$ values (above $400 \mathrm{ppm}$, surface salinity around 31, Fig. 5) in the same area. Druffel et al. (2005) have measured DIC and POM concentrations and analyzed their isotopic composition (radioactive and stable) in the Amazon River mouth and the North Brazil Current area in November 1991 during a low flood period. Their results also show that there might be organic matter remineralization within the inner river plume, because of the $4-10 \%$ excess DIC relative to the conservative mixing line. A more recent study also reports high $p \mathrm{CO}_{2}$ values in the Amazon River estuary (up to $5000 \mathrm{ppm}$ ), originating from excess carbon exported by coastal flooded forest (Abril et al., 2013).

Modeled average sea-to-air $\mathrm{CO}_{2}$ fluxes (1998-2005) in this area (latitudes $0: 10^{\circ} \mathrm{N}$, longitudes $60^{\circ} \mathrm{W}: 30^{\circ} \mathrm{W}$ ) decrease in the TODAY scenario by $3.72 \mathrm{Tg} \mathrm{Ca}^{-1}$, considering all sea surface salinities (Table 3 ). The modeled rivernutrients associated $\mathrm{CO}_{2}$ outgassing occurs at SSS lower than 34.9 , over a surface area of $1.3 \times 10^{12} \mathrm{~m}^{2}$. Nitrogen fix- ation, which also contributes to enhance the biological pump, is higher outside the low surface salinity area (Table 3 ). On a monthly average, this area of low surface salinity is larger and becomes a $\mathrm{CO}_{2}$ sink (supplementary Table 5) between April and July, as also shown in field data (Ternon et al., 2000). However, neither does our model resolution allow further investigations on sea-air gas exchange processes at the river-estuary-ocean mixing zone, nor is this level of detail within the basin-scale scope of this study.

\subsubsection{Impact of African rivers}

In the AFRICA scenario, like in the TODAY scenario, our results suggest an increase in primary production along the African coast, including the Gulf of Guinea and the outflow of the Congo River, with no changes occurring in the Western tropical Atlantic (compared to NO_RIVER, Fig. 7). The modeled primary production in the open and coastal ocean is $3.71 \mathrm{Pg} \mathrm{Ca}^{-1}$ and $0.44 \mathrm{Pg} \mathrm{Ca}^{-1}$, respectively. The overall impact of African rivers to the tropical Atlantic export production is also similar to the S_AMERICA scenario (Table 4).

Interestingly, the similar increases in PP and EP in terms of petagrams of carbon for both scenarios (AFRICA and S_AMERICA) would not be surprising were it not for the fact that the riverine nutrient and carbon inputs to the eastern tropical Atlantic are two to three times smaller than in the western Atlantic (except for DIP). This is probably due to a combination of nutrient trapping in upwelling areas due to slower circulation and an alleviation of Fe limitation conditions (mainly of diatoms) by riverine inputs (Table 4). The previous study from da Cunha et al. (2007) using PISCES-T ocean biogeochemistry model also suggested that river inputs over coastal upwelling areas (eastern ocean margin type) have a higher impact on PP and EP than western margin areas. It is accepted that eastern ocean margins host upwelling systems, provoked by winds blowing towards the Equator, that in turn promote the upwelling of deeper, nutrient-rich waters (Lachkar and Gruber, 2013). In the subtropical and tropical Atlantic, the Canary Upwelling System and the Benguela Upwelling are the most important upwelling areas, followed by seasonal upwelling events in the Gulf of Guinea (Lefèvre, 2009). Among the most common oceanographic features of these systems are indeed high primary and export production rates, as well as a relatively stable shallow mixed layer provoked by an upwelling of the thermocline that prevents deeper water column wind mixing. Shallow mixed layers are also found in coastal ocean areas adjacent to large freshwater inputs (river plumes), forming surface stable low-salinity lenses, as in the western tropical Atlantic off the Amazon and Orinoco outflows (Fig. 10). The eastern upwelling conditions create a stable mixed layer that "traps" nutrients, enhancing PP and EP. In these areas, especially in the sub-tropical eastern Atlantic, the water residence time may also be larger, as suggested in the study of 


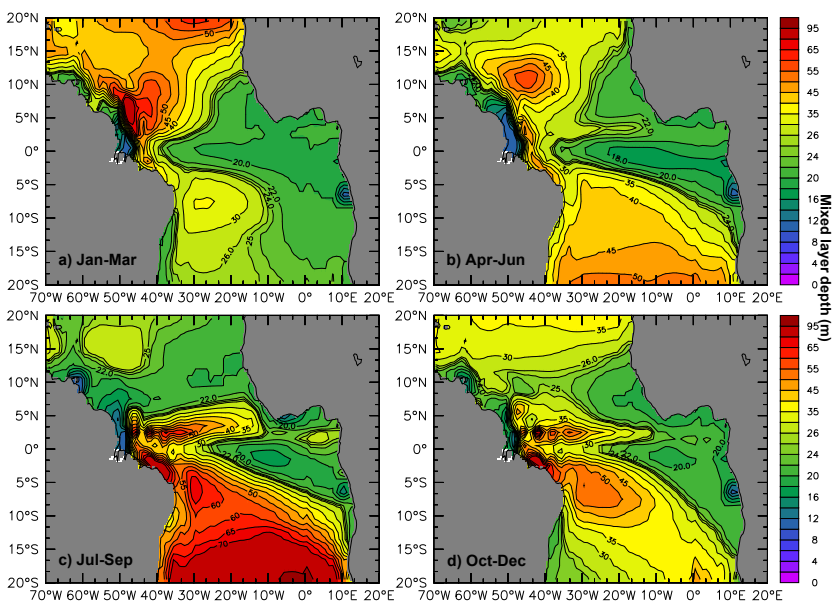

Fig. 10. Modeled average (1998-2005) seasonal surface mixed layer (SML) depths in the tropical Atlantic Ocean, in meters; (a) January-March; (b) April-June; (c) July-September, and (d) October-December. SML values are did not change in the considered TODAY, NO_RIVER, S_AMERICA, and AFRICA scenarios. The coupled model ocean physics (NEMO), i.e. circulation, temperature, salinity, freshwater, heat balance, wind forcing, has not been changed in any of the four simulations considered in this manuscript.

Lachkar and Gruber (2011, 2013), thus enhancing primary production. Modeled primary production in the eastern tropical Atlantic in the NO_RIVER scenario is high in both Canary and Benguela upwelling systems (Fig. 7). Our results suggest that African river nutrients (TODAY and AFRICA scenarios) enhance PP mainly in the Gulf of Guinea and off the Congo River, primarily because river inputs at the Canary and Benguela areas are negligible (Fig. 2). The additional input of river nutrients to an area where high rates of PP and EP occur (eastern Atlantic) has primarily enhanced diatoms production in the coastal ocean (alleviation of nutrient limitation conditions, thus favoring diatoms, which in turn enhances EP; Fig. 8), explaining the relatively higher impact on tropical Atlantic Ocean biogeochemistry by African rivers.

In the eastern tropical Atlantic, the efficiency of the biological pump $\left(E_{\mathrm{BP}}\right)$ has medium values in the main coastal upwelling areas (Mauritania and Benguela) in both the TODAY and NO_RIVER scenarios (Fig. 5). This is typical of low-latitude upwelling areas (Sarmiento and Gruber, 2006), where light and nutrient supplies are high, but the $E_{\mathrm{BP}}$ is medium to low. Additionally, the river inputs to these regions are very low. Nevertheless, $E_{\mathrm{BP}}$ in the Gulf of Guinea and Congo River outflow area (large freshwater and nutrient inputs) decreases when river inputs are added to the model. This suggests that river nutrients increase average nutrient concentrations in the upper layers, and that the combination in a shallow mixed layer decreases the efficiency of the biological pump, as in the western tropical Atlantic.
Despite the large river nutrient inputs (the TODAY and AFRICA scenarios) the coastal ecosystem is still limited by nitrogen and phosphorus. In the AFRICA scenario, riverine inputs of $\mathrm{N}$ and $\mathrm{P}$ are insufficient to maintain coastal $\mathrm{EP}$ (Table 5), corroborating the hypothesis that most of the nutrients necessary to maintain coastal PP and EP are brought by upwelling waters.

\section{River nutrients and the sea-to-air $\mathrm{CO}_{2}$ fluxes in the eastern tropical Atlantic}

Unlike in the western tropical Atlantic, the eastern coastal Atlantic represents only $13 \%$ of the difference in seato-air $\mathrm{CO}_{2}$ fluxes (relative to NO_RIVER, -1.0 and $-7.7 \mathrm{Tg} \mathrm{Ca}^{-1}$, coastal and whole eastern tropical area, respectively). This suggests that nutrient inputs from African rivers may also be sufficient to decrease the sea-to-air $\mathrm{CO}_{2}$ fluxes further off the coastal zone, but not sufficient to decrease the equatorial outgassing.

In the eastern Atlantic, the equatorial and coastal upwelling zones release $\mathrm{CO}_{2}$ to the atmosphere, while in the area south of the South Equatorial Countercurrent (SECC) and near the Congo River outflow, the model results suggest a $\mathrm{CO}_{2}$ sink (Fig. 4) in agreement with in situ data (Lefèvre, 2009; Lefèvre et al., 2008; Parard et al., 2010). Our modeled average sea-to-air $\mathrm{CO}_{2}$ fluxes (1998-2005) suggest an outgassing in the coastal upwelling areas of Mauritania, the Gulf of Guinea and the Benguela Current, and a moderate $\mathrm{CO}_{2}$ sink in the area adjacent to the Congo River outflow in the TODAY and NO_RIVER scenarios. This small coastal sink is due to the mixing effect between river freshwater discharge and seawater (Fig. 4, Table 3). When river inputs are added to the model, this local sink effect is enhanced and extended further north in the coastal ocean to the Ogooué River outflow. Unlike in the western tropical Atlantic, most of the total increase in this $\mathrm{CO}_{2}$ sink occurs outside the coastal ocean $\left(-7.7 \mathrm{Tg} \mathrm{Ca}^{-1}\right.$ versus $-1 \mathrm{Tg} \mathrm{Ca}^{-1}$ for the coastal ocean). Model results suggest that river nutrients are rapidly consumed in the coastal area (large increase in diatom-associated chlorophyll, decrease in coastal rates of $\mathrm{N}$-fixation in the Gulf of Guinea; comparing the TODAY and NO_RIVER scenarios, Supplement Fig. 1, Fig. 6, Table 3), triggering the biological production and enhancing the $\mathrm{CO}_{2}$ sink. Further west, these $\mathrm{CO}_{2}$ undersaturated surface waters mix with equatorial ocean waters, and the surface sea-to-air values are reverted. In the Gulf of Guinea, the average sea-to-air $\mathrm{CO}_{2}$ flux is $-1 \mathrm{Tg} \mathrm{Ca}^{-1}$ (Table 3), but on a monthly basis, modeled sea-to-air $\mathrm{CO}_{2}$ fluxes vary through the year suggesting a sink during July-August, and a source $\left(\mathrm{CO}_{2}\right.$ outgassing $)$ during December-January, in both coastal (SSS $<34$ ) and offshore areas (Supplement Table 5). This mechanism is in agreement with local observations (Lefèvre, 2009). 


\section{Limitations of the model}

We present a study based on three sensitivity tests to estimate the impacts of river nutrients and carbon on the tropical Atlantic Ocean biogeochemistry. However, our approach has limitations. First, our model does not provide a real representation of the coastal zone. Because of its coarse resolution $\left(2^{\circ} \times 0.5^{\circ}-2^{\circ}\right)$, it is not able to resolve circulation patterns like near-shore upwelling, increased tidal mixing in coastal areas, or coastal geomorphological features. A higher resolution of the coastal ocean would likely improve the representation of very productive zones.

Second, we used annual fluxes of riverine nutrients and carbon to the ocean in the ocean biogeochemistry model PlankTOM10. The climatology (on a monthly basis) of river freshwater input is computed in the coupled ocean circulation model NEMO, and was not changed in any scenario. In areas adjacent to strong river input such as the Amazon, Orinoco or Congo, flood and drought periods alter the amount of river nutrient and carbon fluxes. This may have a direct impact in the regional net ecosystem production and sea-air $\mathrm{CO}_{2}$ fluxes. Our river carbon and nutrient input model is a "lumped model" (Kroeze et al., 2012), where river basin and river mouth processes are combined (fewer parameters, based on quasi-empirical statistical studies; Ludwig et al., 1996b; Smith et al., 2003). Their strength is that they can easily be applied to future trends studies or sensitivity analyses (as in our case). Additionally, there is a lack of data, primarily in Africa, South America and Asia (Kroeze et al., 2012), corresponding to this study area. Nevertheless, we concede that considering annual river inputs of carbon and nutrients is indeed a limitation for this study. This type of model considers homogeneous basin processes, and does not consider seasonal variability. Thus, we have chosen this method, also used elsewhere (Buitenhuis et al., 2010; da Cunha et al., 2007; Vogt et al., 2010) given the simplicity of using lumped models to estimate river carbon and nutrient inputs to the ocean.

Third, we use an average concentration for river $\mathrm{Fe}$ and $\mathrm{Si}$. Development of databases considering river basin geology may alter the distribution of riverine $\mathrm{Fe}$ and Si significantly. Fourth, our model does not differentiate terrestrial and marine organic matter reactivity (degradation and mineralization rates, $\mathrm{C}: \mathrm{N}$ ratio). If riverine $\mathrm{OM}$ is more labile than marine $\mathrm{OM}$, the regional budget of sea-to-air $\mathrm{CO}_{2}$ flux and its impact on productivity should be expected to be higher. All these factors can locally enhance or diminish the impact of river inputs in ways that would influence the spatial and temporal distribution of the patterns we identify. In spite of these limitations, our analysis provides estimates of the upper and lower bounds of the basin-scale impact of nutrient and carbon supply by rivers in the tropical Atlantic Ocean, using the most up-to-date tools (Buitenhuis et al., 2013b; da Cunha et al., 2007; Enright et al., 2012) and data available
(Körtzinger, 2003; Lefèvre, 2009; Lefèvre et al., 2008, 2010; Subramaniam et al., 2008).

Fourth, our current version of PlankTOM ocean biogeochemical model includes both diazotrophs and diatoms as plankton functional types, but in its present version it is not able to represent diatom-diazotroph association (DDA), although we fully agree that DDA plays an important role in OM export in the ocean (Foster et al., 2011; Yeung et al., 2012). For lack of data to the contrary, we have no reason to assume the export in an ecosystem that includes DDA would respond differently than one that does not. We warn against this shortcoming in a general way by drawing attention to the ecological resolution as a limiting factor of our model, even though PlankTOM10 is currently one of the most complex global biogeochemical models available.

\section{Conclusions}

We conclude from this sensitivity modeling study that South American river nutrient inputs may have a larger impact on tropical Atlantic coastal primary and export production than African rivers. In our sensitivity tests, we estimate that South American river input to the tropical Atlantic was responsible for up to twice the increase in coastal ocean primary and export production difference between the NO_RIVER and TODAY scenarios.

Nevertheless, considering that: (a) the impact of South American and African rivers is similar for the whole tropical Atlantic Ocean; (b) the African river nutrient and carbon inputs are two to three times smaller, and (c) on the eastern Atlantic, river inputs enter an extended area of the ocean with a shallow mixed layer caused by both upwelling conditions and regionally by the Congo River plume, enhancing the regional primary and export productions off the limits of the coastal ocean, one may conclude that African river inputs' relative impact on the tropical Atlantic Ocean is higher than that of the South American rivers. Da Cunha et al. (2007) found that regional riverine impact on biogeochemistry depends on runoff intensity, local nutrient budgets, and adjacent ocean circulation. The impact may be higher in eastern ocean margin areas with high runoff, because of the nutrient trapping effect of upwelling. In a modeling study using the PISCES model, Giraud et al. (2008) suggested that excess nutrients in coastal areas locally increase the primary and export production if the conditions of nutrient limitation are favorable. In the case of the western tropical Atlantic, riverine nutrients would be able to maintain all the coastal export production, and in the eastern tropical Atlantic, riverine inputs partly alleviate the regional nutrient limitation. These results are confirmed by the relative increase in diatoms-associated chlorophyll (6\% to $14 \%$ of the total surface Chla) in the coastal ocean, since diatoms have a higher nutrient requirement than the other phytoplankton groups. Our results suggest also that river nutrient inputs may enhance $\mathrm{N}$-fixation 
in the western Atlantic Ocean, and thus alleviate open ocean nitrogen limitation. The increase in $\mathrm{N}$-fixation equivalent in carbon is proportional to the increase in primary and export productions. The carbon equivalent of the total fixed nitrogen in the tropical Atlantic in the TODAY scenario may sustain up to $14 \%$ of the export production.

The increase in primary and export production has some impact on the sea-to-air $\mathrm{CO}_{2}$ fluxes. Considering the whole tropical Atlantic, our results suggest a decrease in the $\mathrm{CO}_{2}$ outgassing of $5 \mathrm{Tg} \mathrm{Ca}^{-1}$ (TODAY scenario - NO_RIVER). In the eastern tropical Atlantic, the TODAY and AFRICA scenarios suggest that the increase in production (and thus in the biological carbon pump) may slightly reverse the physical processes (upwelling) dominating the sea-to-air $\mathrm{CO}_{2}$ flux. In the western tropical Atlantic, our results suggest that the increased production, organic matter respiration and river DIC outgassing in the TODAY and S_AMERICA scenarios enhances the $\mathrm{CO}_{2}$ outgassing, and this occurs almost exclusively in the coastal ocean. This is in agreement with field studies that measured either high $\mathrm{pCO}_{2}$ values in surface waters of the Amazon estuary (Abril et al., 2013; Pfeil et al., 2012b; Weiss and Goyet, 2011) or found excess DIC (4\% to $10 \%)$ relative to the conservative mixing line between the Amazon River mouth and the North Brazil Current area (Druffel et al., 2005).

\section{Supplementary material related to this article is available online at http://www.biogeosciences.net/10/ 6357/2013/bg-10-6357-2013-supplement.pdf.}

Acknowledgements. We thank C. Le Quéré for her support and very helpful comments during the preparation of this manuscript, Petra Döll for providing the DDM30 file (GlobalNews project), the SeaWiFS team, NOAA, the Research Computing Service at the University of East Anglia for the use of the Linux cluster, C. Enright for making the atmospheric forcing files, and the two anonymous reviewers for their comments on and criticisms of this manuscript. The authors wish to acknowledge use of the Ferret and Ocean Data View (Schlitzer, R., available at http://odv.awi.de) programs for analysis and graphics in this paper. Ferret is a product of NOAA's Pacific Marine Environmental Laboratory (available at http://ferret.pmel.noaa.gov/Ferret/). This study is part of the Dynamic Green Ocean Project (available at http://lgmacweb.env.uea.ac.uk/green_ocean/index.shtml). L. C. da Cunha was funded by EU contract HPMD-CT-2000-00038 and by GLOMAR/MARUM, Universität Bremen.

Edited by: A. Bricaud

\section{References}

Abril, G., Deborde, J., Savoye, N., Mathieu, F., Moreira-Turcq, P., Artigas, F., Meziane, T., Takiyama, L. R., de Souza, M. S., and
Seyler, P.: Export of 13C-depleted dissolved inorganic carbon from a tidal forest bordering the Amazon estuary, Estuar. Coast. Shelf Sc., 129, 23-27, doi:10.1016/j.ecss.2013.06.020, 2013.

Behrenfeld, M. J.: Carbon-based ocean productivity and phytoplankton physiology from space, Global Biogeochem. Cy., 19, GB1006, doi:10.1029/2004GB002299, 2005.

Binet, D.: Neritic phytoplankton and primary production of the seasonal upwelling areas in the Gulf of Guinea, Oceanogr. Trop., 18, 331-355, 1983.

Boyle, E. A., Edmond, J. M., and Sholkovitz, E. R.: The mechanism of iron removal in estuaries, Geochim. Cosmochim. Ac., 41, 1313-1324, doi:10.1016/0016-7037(77)90075-8, 1977.

Buitenhuis, E. T., Le Quéré, C., Aumont, O., Beaugrand, G., Bunker, A., Hirst, A., Ikeda, T., O'Brien, T., Piontkovski, S., and Straile, D.: Biogeochemical fluxes through mesozooplankton., Global Biogeochem. Cy., 20, GB2003, doi:10.1029/2005GB002511, 2006.

Buitenhuis, E. T., Rivkin, R. B., Sailley, S., and Le Quéré, C.: Biogeochemical fluxes through microzooplankton, Global Biogeochem. Cy., 24, n/a-n/a, doi:10.1029/2009GB003601, 2010.

Buitenhuis, E. T., Vogt, M., Moriarty, R., Bednaršek, N., Doney, S. C., Leblanc, K., Le Quéré, C., Luo, Y.-W., O’Brien, C., O’Brien, T., Peloquin, J., Schiebel, R., and Swan, C.: MAREDAT: towards a world atlas of MARine Ecosystem DATa, Earth Syst. Sci. Data, 5, 227-239, doi:10.5194/essd-5-227-2013, 2013a.

Buitenhuis, E. T., Hashioka, T., and Le Quéré, C.: Combined constraints on ocean primary production and phytoplankton biomass from observations and a model, Global Biogeochem. Cy., in press, doi:10.1002/gbc.20074, 2013b.

Cadée, G. C.: Primary production and chlorophyll in the Zaire river, estuary and plume, Neth. J. Sea Res., 12, 368-381, doi:10.1016/0077-7579(78)90040-6, 1978.

Carpenter, E. J. and Capone, D. G.: Chapter 4 - Nitrogen Fixation in the Marine Environment, in: Nitrogen in the Marine Environment (2nd Edn.), Academic Press, San Diego, 141-198, 2008.

Chen, C.-T. A., Huang, T.-H., Fu, Y.-H., Bai, Y., and He, X.: Strong sources of $\mathrm{CO}_{2}$ in upper estuaries become sinks of $\mathrm{CO}_{2}$ in large river plumes, Curr. Opin. Environ. Sustain., 4, 179-185, doi:10.1016/j.cosust.2012.02.003, 2012.

Chester, R. and Jickells, T. D.: Marine Geochemistry - 3rd Edn., John Wiley \& Sons, 2012.

Cooley, S. R., Coles, V. J., Subramaniam, A., and Yager, P. L.: Seasonal variations in the Amazon plume-related atmospheric carbon sink, Global Biogeochem. Cy., 21, GB3014, doi:10.1029/2006GB002831, 2007.

Corredor, J. E., Morell, J. M., Lopez, J. F., Armstrong, R. A., Dieppa, A., Cabanillas, C., Cabrera, A., and Hensley, V.: Remote continental forcing of phytoplankton biogeochemistry: Observations across the "Caribbean-Atlantic front," Geophys. Res. Lett., 30, 2057, doi:10.1029/2003GL018193, 2003.

Coynel, A., Seyler, P., Etcheber, H., Meybeck, M., and Orange, D.: Spatial and seasonal dynamics of total suspended sediment and organic carbon species in the Congo River, Global Biogeochem. Cy., 19, GB4019, doi:10.1029/2004GB002335, 2005.

Da Cunha, L. C., Buitenhuis, E. T., Le Quéré, C., Giraud, X., and Ludwig, W.: Potential impact of changes in river nutrient supply on global ocean biogeochemistry, Global Biogeochem. Cy., 21, GB4007, doi:10.1029/2006GB002718, 2007. 
Dai, A. and Trenberth, K. E.: Estimates of freshwater discharge from continents: Latitudinal and seasonal variations, J. Hydrometeorol., 3, 660-687, 2002.

Dale, B., Dale, A. L., and Jansen, J. H. F.: Dinoflagellate cysts as environmental indicators in surface sediments from the Congo deep-sea fan and adjacent regions, Palaeogeogr. Palaeocl., 185, 309-338, doi:10.1016/S0031-0182(02)00380-2, 2002.

Deutsch, C., Sarmiento, J. L., Sigman, D. M., Gruber, N., and Dunne, J. P.: Spatial coupling of nitrogen inputs and losses in the ocean, Nature, 445, 163-167, doi:10.1038/nature05392, 2007.

Dittmar, T. and Kattner, G.: Recalcitrant dissolved organic matter in the ocean: major contribution of small amphiphilics, Mar. Chem., 82, 115-123, doi:10.1016/S0304-4203(03)00068-9, 2003.

Döll, P. and Lehner, B.: Validation of a new global 30-min drainage direction map, J. Hydrol., 258, 214-231, doi:10.1016/S00221694(01)00565-0, 2002.

Druffel, E. R. M., Bauer, J. E., and Griffin, S.: Input of particulate organic and dissolved inorganic carbon from the Amazon to the Atlantic Ocean, Geochemistry, Geophysics, Geosystems, 6, Q03009, doi:10.1029/2004GC000842, 2005.

Dumont, E., Harrison, J. A., Kroeze, C., Bakker, E. J., and Seitzinger, S. P.: Global distribution and sources of dissolved inorganic nitrogen export to the coastal zone: Results from a spatially explicit, global model, Global Biogeochem. Cy., 19, GB4S02, doi:10.1029/2005GB002488, 2005.

Enright, C., Buitenhuis, E. T., and Le Quéré, C.: Description of the PlankTOM10 equations, available at: http://lgmacweb.env.uea.ac.uk/green_ocean/model/ PlankTOM10_equations_Feb2012.pdf, 2012.

Fernández, A., Mouriño-Carballido, B., Bode, A., Varela, M., and Marañón, E.: Latitudinal distribution of Trichodesmium spp. and $\mathrm{N}_{2}$ fixation in the Atlantic Ocean, Biogeosciences, 7, 31673176, doi:10.5194/bg-7-3167-2010, 2010.

Foster, R. A., Kuypers, M. M. M., Vagner, T., Paerl, R. W., Musat, N., and Zehr, J. P.: Nitrogen fixation and transfer in open ocean diatom-cyanobacterial symbioses, ISME J., 5, 1484-1493, doi:10.1038/ismej.2011.26, 2011.

Garcia, H. E., Locarnini, R. A., Boyer, T. P., and Antonov, J. I.: World Ocean Atlas 2005, Volume 3: Dissolved Oxygen, Apparent Oxygen Utilization, and Oxygen Saturation, in: World Ocean Atlas 2005, edited by: Levitus, S., US Government Printing Office - NOAA Atlas NESDIS 62, Washington, DC, p. 342, $2006 \mathrm{a}$.

Garcia, H. E., Locarnini, R. A., Boyer, T. P., and Antonov, J. I.: World Ocean Atlas 2005, Volume 4: Nutrients (phosphate, nitrate, silicate), in: World Ocean Atlas 2005, edited by S. Levitus, NOAA Atlas NESDIS 64, US Government Printing Office, Washington, DC, p. 396, 2006b.

Giraud, X., Le Quéré, C., and da Cunha, L. C.: Importance of coastal nutrient supply for global ocean biogeochemistry, Global Biogeochem. Cy., 22, GB2025, doi:10.1029/2006GB002717, 2008.

Hansell, D. A., Kadko, D., and Bates, N. R.: Degradation of terrigenous dissolved organic carbon in the western Arctic Ocean, Science, 304, 858-861, doi:10.1126/science.1096175, 2004.

Hardman-Mountford, N. J., Richardson, A. J., Agenbag, J. J., Hagen, E., Nykjaer, L., Shillington, F. A., and Villacastin, C.: Ocean climate of the South East Atlantic observed from satellite data and wind models, Progr. Oceanogr., 59, 181-221, doi:10.1016/j.pocean.2003.10.001, 2003.
Harrison, J. A., Caraco, N., and Seitzinger, S. P.: Global patterns and sources of dissolved organic matter export to the coastal zone: Results from a spatially explicit, global model, Global Biogeochem. Cy., 19, GB4S04, doi:10.1029/2005GB002480, 2005a.

Harrison, J. A., Seitzinger, S. P., Bouwman, A. F., Caraco, N., Beusen, A. H. W., and Vörösmarty, C. J.: Dissolved inorganic phosphorus export to the coastal zone: results from a spatially explicit, global model, Global Biogeochem. Cy., 19, GB4S03, doi:10.1029/2004GB002357, 2005b.

Hu, C., Montgomery, E. T., Schmitt, R. W., and Muller-Karger, F. E.: The dispersal of the Amazon and Orinoco River water in the tropical Atlantic and Caribbean Sea: Observation from space and S-PALACE floats, Deep-Sea Res. Pt. II, 51, 1151-1171, doi:10.1016/j.dsr2.2004.04.001, 2004.

Humborg, C., Conley, D. J., Rahm, L., Wulff, F., Cociasu, A., and Ittekkot, V.: Silicon Retention in River Basins: Far-reaching Effects on Biogeochemistry and Aquatic Food Webs in Coastal Marine Environments, AMBIO, 29, 45-50, doi:10.1579/0044-744729.1.45, 2000.

Jones, C. D.: Strong carbon cycle feedbacks in a climate model with interactive $\mathrm{CO}_{2}$ and sulphate aerosols, Geophys. Res. Lett., 30, 1479, doi:10.1029/2003GL016867, 2003.

Kalnay, E., Kanamitsu, M., Kistler, R., Collins, W., Deaven, D., Gandin, L., Iredell, M., Saha, S., White, G., Woollen, J., Zhu, Y., Leetmaa, A., Reynolds, R., Chelliah, M., Ebisuzaki, W., Higgins, W. Janowiak, J., Mo, K. C., Ropelewski, C., Wang, J., Jenne, R., and Joseph, D.: The NCEP/NCAR 40-Year Reanalysis Project, B. Am. Meteorol. Soc., 77, 437-471, doi:10.1175/15200477(1996)077<0437:TNYRP>2.0.CO;2, 1996.

Körtzinger, A.: A significant $\mathrm{CO}_{2}$ sink in the tropical Atlantic Ocean associated with the Amazon River plume, Geophys. Res. Lett., 30, 2-5, doi:10.1029/2003GL018841, 2003.

Korzoun, V. I., Sokolov, A. A., Budyko, M. I., Voskresensky, G. P., Kalinin, A. A., Konoplyantsev, E. S., Korotkevitch, E. S., and Lvovich, M. I.: Atlas of World Water Balance, UNESCO-Press, Paris, 1977.

Kroeze, C., Bouwman, L., and Seitzinger, S.: Modeling global nutrient export from watersheds, Curr. Opin. Environ. Sust., 4, 195202, doi:10.1016/j.cosust.2012.01.009, 2012.

Lachkar, Z. and Gruber, N.: What controls biological production in coastal upwelling systems? Insights from a comparative modeling study, Biogeosciences, 8, 2961-2976, doi:10.5194/bg-82961-2011, 2011.

Lachkar, Z. and Gruber, N.: Response of biological production and air-sea $\mathrm{CO}_{2}$ fluxes to upwelling intensification in the California and Canary Current Systems, J. Mar. Syst., 109-110, 149-160, doi:10.1016/j.jmarsys.2012.04.003, 2013.

Lefèvre, N.: Low $\mathrm{CO}_{2}$ concentrations in the Gulf of Guinea during the upwelling season in 2006, Mar. Chem., 113, 93-101, doi:10.1016/j.marchem.2009.01.001, 2009.

Lefèvre, N. and Merlivat, L.: Carbon and oxygen net community production in the eastern tropical Atlantic estimated from a moored buoy, Global Biogeochem. Cy., 26, GB1009, doi:10.1029/2010GB004018, 2012.

Lefèvre, N., Guillot, A., Beaumont, L., and Danguy, T.: Variability of $\mathrm{fCO}_{2}$ in the Eastern Tropical Atlantic from a moored buoy, J. Geophys. Res., 113, C01015, doi:10.1029/2007JC004146, 2008. 
Lefèvre, N., Diverrrès, D., Gallois, F., and DIVERRÈS, D.: Origin of $\mathrm{CO}_{2}$ undersaturation in the western tropical Atlantic, Tellus B, 62, 595-607, doi:10.1111/j.1600-0889.2010.00475.x, 2010.

Lewis, W. M. and Saunders, J. F.: Concentration and transport of dissolved and suspended substances in the Orinoco River, Biogeochemistry, 7, 203-240, doi:10.1007/BF00004218, 1989.

Lohan, M. C. and Bruland, K. W.: Importance of vertical mixing for additional sources of nitrate and iron to surface waters of the Columbia River plume: Implications for biology, Mar. Chem., 98, 260-273, doi:10.1016/j.marchem.2005.10.003, 2006.

Ludwig, W. and Probst, J.-L.: River sediment discharge to the oceans; present-day controls and global budgets, Am. J. Sci., 298, 265-295, doi:10.2475/ajs.298.4.265, 1998.

Ludwig, W., AmiotteSuchet, P., and Probst, J. L.: River discharges of carbon to the world's oceans: Determining local inputs of alkalinity and of dissolved and particulate organic carbon, CR Acad. Sci. II A, 323, 1007-1014, 1996a.

Ludwig, W., Probst, J.-L., and Kempe, S.: Predicting the oceanic input of organic carbon by continental erosion, Global Biogeochem. Cy., 10, 23-41, doi:10.1029/95GB02925, 1996b.

Luo, Y.-W., Doney, S. C., Anderson, L. A., Benavides, M., BermanFrank, I., Bode, A., Bonnet, S., Boström, K. H., Böttjer, D., Capone, D. G., Carpenter, E. J., Chen, Y. L., Church, M. J., Dore, J. E., Falcón, L. I., Fernández, A., Foster, R. A., Furuya, K., Gómez, F., Gundersen, K., Hynes, A. M., Karl, D. M., Kitajima, S., Langlois, R. J., LaRoche, J., Letelier, R. M., Marañón, E., McGillicuddy Jr., D. J., Moisander, P. H., Moore, C. M., Mouriño-Carballido, B., Mulholland, M. R., Needoba, J. A., Orcutt, K. M., Poulton, A. J., Rahav, E., Raimbault, P., Rees, A. P., Riemann, L., Shiozaki, T., Subramaniam, A., Tyrrell, T., TurkKubo, K. A., Varela, M., Villareal, T. A., Webb, E. A., White, A. E., Wu, J., and Zehr, J. P.: Database of diazotrophs in global ocean: abundance, biomass and nitrogen fixation rates, Earth Syst. Sci. Data, 4, 47-73, doi:10.5194/essd-4-47-2012, 2012.

Madec, G. and NEMO-Team: NEMO ocean engine, Note du Po, Institut Pierre-Simon Laplace (IPSL), France, Paris, available at: http://www.nemo-ocean.eu/content/download/21612/97924/ file/NEMO_book_3_4.pdf, 2008.

Manizza, M., Le Quéré, C., Watson, A. J., and Buitenhuis, E. T.: Bio-optical feedbacks among phytoplankton, upper ocean physics and sea-ice in a global model, Geophys. Res. Lett., 32, L05603, doi:10.1029/2004GL020778, 2005.

Manizza, M., Follows, M. J., Dutkiewicz, S., Menemenlis, D., McClelland, J. W., Hill, C. N., Peterson, B. J., and Key, R. M.: A model of the Arctic Ocean carbon cycle, J. Geophys. Res., 116, C12020, doi:10.1029/2011JC006998, 2011.

Martin, J.-M. and Meybeck, M.: Elemental mass-balance of material carried by major world rivers, Mar. Chem., 7, 173-206, doi:10.1016/0304-4203(79)90039-2, 1979.

Martin, J.-M. and Whitfield, M.: The significance of the river input of chemical elements to the ocean, in: Trace metals in sea water, edited by: Wong, C. S., Boyle, E., Bruland, K. W., Burton, J. D., and Goldberg, E. D., Plenum, New York, 265-296, 1983.

Meybeck, M.: The global change of continental aquatic systems: dominant impacts of human activities, Water Sci. Technol., 49, 73-83, 2004.

Molleri, G. S. F., Novo, E., and Kampel, M.: Space-time variability of the Amazon River plume based on satellite ocean color, Cont. Shelf Res., 30, 342-352, doi:10.1016/j.csr.2009.11.015, 2010.
Monteiro, F. M., Follows, M. J., and Dutkiewicz, S.: Distribution of diverse nitrogen fixers in the global ocean, Global Biogeochem. Cy., 24, GB3017, doi:10.1029/2009GB003731, 2010.

Moore, J. K., Doney, S. C., and Lindsay, K.: Upper ocean ecosystem dynamics and iron cycling in a global threedimensional model, Global Biogeochem. Cy., 18, GB4028, doi:10.1029/2004GB002220, 2004.

Parard, G., Lefèvre, N., and Boutin, J.: Sea water fugacity of $\mathrm{CO}_{2}$ at the PIRATA mooring at $6^{\circ} \mathrm{S}, 10^{\circ} \mathrm{W}$, Tellus B, 62, 636-648, doi:10.1111/j.1600-0889.2010.00503.x, 2010.

Paulson, C. A. and Simpson, J. J.: Irradiance Measurements in the Upper Ocean, J. Phys. Oceanogr., 7, 952-956, doi:10.1175/15200485(1977)007<0952:IMITUO>2.0.CO;2, 1977.

Pfeil, B., Olsen, A., Bakker, D. C. E., Hankin, S., Koyuk, H., Kozyr, A., Malczyk, J., Manke, A., Metzl, N., Sabine, C. L., Akl, J., Alin, S. R., Bellerby, R. G. J., Borges, A., Boutin, J., Brown, P. J., Cai, W.-J., Chavez, F. P., Chen, A., Cosca, C., Fassbender, A. J., Feely, R. A., González-Dávila, M., Goyet, C., HardmanMountford, N., Heinze, C., Hood, M., Hoppema, M., Hunt, C. W., Hydes, D., Ishii, M., Johannessen, T., Jones, S. D., Key, R. M., Körtzinger, A., Landschützer, P., Lauvset, S. K., Lefèvre, N., Lenton, A., Lourantou, A., Merlivat, L., Midorikawa, T., Mintrop, L., Miyazaki, C., Murata, A., Nakadate, A., Nakano, Y., Nakaoka, S., Nojiri, Y., Omar, A. M., Padin, X. A., Park, G.-H., Paterson, K., Perez, F. F., Pierrot, D., Poisson, A., Ríos, A. F., Santana-Casiano, J. M., Salisbury, J., Sarma, V. V. S. S., Schlitzer, R., Schneider, B., Schuster, U., Sieger, R., Skjelvan, I., Steinhoff, T., Suzuki, T., Takahashi, T., Tedesco, K., Telszewski, M., Thomas, H., Tilbrook, B., Tjiputra, J., Vandemark, D., Veness, T., Wanninkhof, R., Watson, A. J., Weiss, R., Wong, C. S., and Yoshikawa-Inoue, H.: A uniform, quality controlled Surface Ocean $\mathrm{CO}_{2}$ Atlas (SOCAT), Earth Syst. Sci. Data Discuss., 5, 735-780, doi:10.5194/essdd-5-735-2012, 2012a.

Pfeil, G. B., Olsen, A., and Bakker, D. C. E.: Surface Ocean $\mathrm{CO}_{2}$ Atlas (SOCAT) V1.4, doi:10.1594/PANGAEA.767698, 2012b.

Probst, J. L., Mortatti, J., and Tardy, Y.: Carbon river fluxes and weathering $\mathrm{CO}_{2}$ consumption in the Congo and Amazon river basins, Appl. Geochem., 9, 1-13, doi:10.1016/08832927(94)90047-7, 1994.

Le Quéré, C., Harrison, S. P., Prentice, I. C., Buitenhuis, E. T., Aumont, O., Bopp, L., Claustre, H., Da Cunha, L. C., Geider, R., Giraud, X., Klaas, C., et al.: Ecosystem dynamics based on plankton functional types for global ocean biogeochemistry models, Glob. Change Biol., 11, 2016-2040, doi:10.1111/j.13652486.2005.1004.x, 2005.

Reynolds, S. E., Mather, R. L., Wolff, G. A., Williams, R. G., Landolfi, A., Sanders, R., and Woodward, E. M. S.: How widespread and important is N 2 fixation in the North Atlantic Ocean, Global Biogeochem. Cy., 21, GB4015, doi:10.1029/2006GB002886, 2007.

Sarmiento, J. L. and Gruber, N.: Ocean biogeochemical dynamics, Princeton University Press, available at: http://press.princeton. edu/titles/8223.html, 2006.

Sarthou, G., Timmermans, K. R., Blain, S., and Tréguer, P.: Growth physiology and fate of diatoms in the ocean: a review, J. Sea Res., 53, 25-42, doi:10.1016/j.seares.2004.01.007, 2005.

Schlitzer, R.: Export Production in the Equatorial and North Pacific Derived from Dissolved Oxygen, $\mathrm{Nu}-$ 
trient and Carbon Data, J. Oceanogr., 60, 53-62, doi:10.1023/B:JOCE.0000038318.38916.e6, 2004.

Schneider, R. R., Price, B., Müller, P. J., Kroon, D., and Alexander, I.: Monsoon related variations in Zaire (Congo) sediment load and influence of fluvial silicate supply on marine productivity in the east equatorial Atlantic during the last 200,000 years, Paleoceanography, 12, 463-481, doi:10.1029/96PA03640, 1997.

Sholkovitz, E. R.: The flocculation of dissolved Fe, Mn, Al, Cu, Ni, $\mathrm{Co}$ and $\mathrm{Cd}$ during estuarine mixing, Earth Planetary Sci. Lett., 41, 77-86, doi:10.1016/0012-821X(78)90043-2, 1978.

Smith, S. V., Swaney, D. P., Talaue-McManus, L., Bartley, J. D., Sandhei, P. T., McLaughlin, C. J., Dupra, V. C., Crossland, C. J., Buddemeier, R. W., Maxwell, B. A., and Wulff, F.: Humans, Hydrology, and the Distribution of Inorganic Nutrient Loading to the Ocean, BioScience, 53, 235, doi:10.1641/00063568(2003)053[0235:HHATDO]2.0.CO;2, 2003.

Smith, W. O. and Demaster, D. J.: Phytoplankton biomass and productivity in the Amazon River plume: correlation with seasonal river discharge, Cont. Shelf Res., 16, 291-319, doi:10.1016/0278-4343(95)00007-N, 1996.

Subramaniam, A., Yager, P. L., Carpenter, E. J., Mahaffey, C., Björkman, K., Cooley, S., Kustka, A. B., Montoya, J. P., SañudoWilhelmy, S. A., Shipe, R., and Capone, D. G.: Amazon River enhances diazotrophy and carbon sequestration in the tropical North Atlantic Ocean, P. Natl. Acad. Sci. USA, 105, 1046010465, doi:10.1073/pnas.0710279105, 2008.

Suntharalingam, P., Buitenhuis, E., Le Quéré, C., Dentener, F., Nevison, C., Butler, J. H., Bange, H. W., and Forster, G.: Quantifying the impact of anthropogenic nitrogen deposition on oceanic nitrous oxide, Geophys. Res. Lett., 39, L07605, doi:10.1029/2011GL050778, 2012.

Tagliabue, A., Mtshali, T., Aumont, O., Bowie, A. R., Klunder, M. B., Roychoudhury, A. N., and Swart, S.: A global compilation of dissolved iron measurements: focus on distributions and processes in the Southern Ocean, Biogeosciences, 9, 2333-2349, doi:10.5194/bg-9-2333-2012, 2012.

Ternon, J. ., Oudot, C., Dessier, A., and Diverres, D.: A seasonal tropical sink for atmospheric $\mathrm{CO}_{2}$ in the Atlantic ocean: the role of the Amazon River discharge, Mar. Chem., 68, 183-201, doi:10.1016/S0304-4203(99)00077-8, 2000.
Tréguer, P., Nelson, D. M., Van Bennekom, A. J., Demaster, D. J., Leynaert, A., and Quéguiner, B.: The silica balance in the world ocean: a reestimate, Science, 268, 375-379, doi:10.1126/science.268.5209.375, 1995.

Tyrrell, T., Marañón, E., Poulton, A. J., Bowie, A. R., Harbour, D. S., and Woodward, E. M. S.: Large-scale latitudinal distribution of Trichodesmium spp. in the Atlantic Ocean, J. Plankton Res., 25, 405-416, doi:10.1093/plankt/25.4.405, 2003.

UNPD: United Nations Population Division, World Population Prospects: The 2002 Revision, vol. III, Analytical Report, edited by: Department of Economical and Social Affairs, United Nations, New York, available at: http://www.un.org/esa/population/ publications/wpp2002/WPP2002_VOL_3.pdf, 2004.

Vogt, M., Vallina, S. M., Buitenhuis, E. T., Bopp, L., and Le Quéré, C.: Simulating dimethylsulphide seasonality with the Dynamic Green Ocean Model PlankTOM5, J. Geophys. Res., 115, C06021, doi:10.1029/2009JC005529, 2010.

Voss, M.: Patterns of nitrogen fixation along $10^{\circ} \mathrm{N}$ in the tropical Atlantic, Geophys. Res. Lett., 31, L23S09, doi:10.1029/2004GL020127, 2004.

Weiss, R. F.: Underway physical oceanography and carbon dioxide measurements during KNORR cruise TTO-TAS_leg_1, doi:10.1594/PANGAEA.144811, 2011.

Weiss, R. F. and Goyet, C.: Underway physical oceanography and carbon dioxide measurements during KNORR cruise WOCE_A15-AR15, doi:10.1594/PANGAEA.144811, 2011.

Ye, Y., Völker, C., and Wolf-Gladrow, D. A.: A model of Fe speciation and biogeochemistry at the Tropical Eastern North Atlantic Time-Series Observatory site, Biogeosciences, 6, 20412061, doi:10.5194/bg-6-2041-2009, 2009.

Yeung, L. Y., Berelson, W. M., Young, E. D., Prokopenko, M. G., Rollins, N., Coles, V. J., Montoya, J. P., Carpenter, E. J., Steinberg, D. K., Foster, R. A., Capone, D. G., and Yager, P. L.: Impact of diatom-diazotroph associations on carbon export in the Amazon River plume, Geophys. Res. Lett., 39, L18609, doi:10.1029/2012GL053356, 2012. 